\title{
Syntheses, characterization, and anti-cancer activities of pyridine-amide based compounds containing appended phenol or catechol groups
}

\author{
AFSAR ALI $^{\mathrm{a}}$, DEEPAK BANSAL ${ }^{\mathrm{a}}$, NAGENDRA K KAUSHIK ${ }^{\mathrm{b}}$, NEHA KAUSHIK $^{\mathrm{b}}$, \\ EUN HA CHOI ${ }^{\mathrm{b}}$ and RAJEEV GUPTA ${ }^{\mathrm{a}, *}$ \\ ${ }^{a}$ Department of Chemistry, University of Delhi, Delhi 110 007, India \\ bPlasma Bioscience Research Center, Kwangwoon University, Seoul 139 701, South Korea \\ e-mail:rgupta@chemistry.du.ac.in
}

MS received 26 December 2013; revised 26 March 2014; accepted 9 April 2014

\begin{abstract}
Several pyridine-amide compounds appended with phenol/catechol groups are synthesized. These compounds consist of protected or deprotected phenol/catechol groups and offer pyridine, amide, and phenol/catechol functional groups. All compounds have been well-characterized by various spectroscopic methods, elemental analysis, thermal studies, and crystallography. The biological activities of all compounds were investigated while a few compounds significantly decreased the metabolic viability, growth and clonogenicity of T98G cells in dose dependent manner. Accumulation of ROS was observed in T98G cells, which displayed a compromised redox status as evident from increased cellular Caspase 3/7 activity and formation of micronuclei. The in silico pharmacokinetic studies suggest that all compounds have good bioavailability, water solubility and other drug-like parameters. A few compounds were identified as the lead molecules for future investigation due to their: (a) high activity against T98G brain, H-460 lung, and SNU-80 thyroid cancer cells; (b) low cytotoxicity in non-malignant HEK and MRC-5 cells; (c) low toxic risks based on in silico evaluation; (d) good theoretical oral bioavailability according to Lipinski 'rule of five' pharmacokinetic parameters; and (e) better drug-likeness and drug-score values.
\end{abstract}

Keywords. Amide; phenol/catechol; Growth kinetics; T98G cell; In-silico Pharmacokinetics.

\section{Introduction}

An amide linkage, - $\mathrm{CO}-\mathrm{NH}-$, is a core structural unit in the skeleton of proteins and pervasive in nature. Amide-based molecules are considered to be suitable for drug research due to their biological compatibility. Development of new amide derivatives has been actively persuaded due to their potent application in vast biological activities, such as fungicidal, ${ }^{1-4}$ herbicidal, ${ }^{5-8}$ insecticidal, ${ }^{9,10}$ anti-cancer, ${ }^{11,12}$ and antibacterial, ${ }^{13}$ etc. In this context, derivatives of pyridinecarboxamide are reported to show important analgesic, anti-inflammatory and anti-pyretic activities. ${ }^{14}$ Many diamide derivatives have also exhibited higher larvicidal activity against culex mosquito which acts as vectors for the transmission of serious diseases, such as filariasis, West Nile virus, dengue, yellow fever, chikungunya and other encephalitides. ${ }^{15}$ Reports have also shown the usefulness of $N, N^{\prime}$-dipyridyl2,6-pyridinedicarboxamides in treatment of atherosclerosis. ${ }^{14}$ We have also reported the coordination complexes of several amide-based compounds displaying

*For correspondence significant anti-cancer and anti-microbial activities with negligible or no toxicity against the normal cells. ${ }^{16}$

Notably, the pharmacological properties of phenol and catechol based molecules are well-studied due to their potent anti-oxidant properties in addition to several other important biological roles. Phenol (or catechol) containing copolymers are known to have immune-stimulating and anti-tumor activities, as these molecules adopt a rigid conformation which favours the activation of immune-competent cells. ${ }^{17}$ Further, few catechol derivatives are reported to have analgesic and anaesthetic action and their activity decreases with the size of the molecule. ${ }^{18}$

Importantly, presence of several hydroxyl groups (phenol or catechol) in a molecule is expected to enhance their affinity toward protein and nucleic acid due to the presence of potential hydrogen bond (H-bond) donors and acceptors, as has been elegantly shown with synthetic systems. ${ }^{19-28}$ Interestingly, despite potential application of both amide group as well as phenol/catechol synthons; hybrid molecules have largely remained unexplored. Recently, an amide derivative containing phenol/catechol group showed radical scavenging activities for the treatment of skin 
ageing, similar to that of trans-resveratrol. ${ }^{29}$ This paper reports a series of amide-based molecules appended with phenol and catechol groups and their activities against various cancer and non-malignant human cells. After in vitro screening on various malignant and nonmalignant human cells, we have also shown the growth kinetics, reactive oxygen species (ROS) generations, clonogenicity, caspase 3/7 activity and in silico pharmacokinetics studies of such molecules.

\section{Experimental}

\subsection{Chemicals}

All reagents were obtained from the Sigma-Aldrich and used without further purification. Solvents were purified and dried according to the literature methods. ${ }^{30}$ The 3-[4,5-dimethylthiazol-2-yl]-2,5-diphenyl tetrazoliumbromide, bis-benzimidazole derivative, N-[2hydroxyethyl]piperazine-N-[2-ethanesulfonic acid] buffer, trypan blue, crystal violet dye and trypsin-EDTA were obtained from the Sigma Chemical Co., Korea. Dulbecco's modified phosphate buffered saline (PBS), Dulbecco's modified eagle's medium (DMEM), fetal bovine serum (FBS) were obtained from the Hyclone, Korea. 2,7-Dichlorofluorescin diacetate (DCFH-DA) was purchased from Molecular probes and Caspase 3/7Glo assay kit was obtained from Promega (Madison USA).

\subsection{Human cell culture}

The T98G brain cancer, H-460 lung cancer, SNU-80 thyroid cancer, non-malignant HEK kidney and nonmalignant MRC-5 lung cells were purchased from the Korean Cell Line Bank. These cell lines were cultured in $75 \mathrm{~cm}^{2}$ culture flasks using DMEM supplemented with $10 \%$ FBS, $1 \%$ non-essential amino acids, $1 \%$ glutamine, $1 \%$ penicillin $(100 \mathrm{IU} / \mathrm{mL})$ and streptomycin $(100 \mathrm{mg} / \mathrm{mL})$ or by the distributor instructions. All cultures were maintained at $37^{\circ} \mathrm{C}, 95 \%$ relative humidity and $5 \% \mathrm{CO}_{2}$. Prior to each test, the cells were harvested by centrifugation at $1000 \mathrm{rpm}$ for $5 \mathrm{~min}$ and diluted by upto $10^{4}-10^{5}$ cells $/ \mathrm{mL}$ for experiment. Stock cultures were passaged every third day after centrifugation at $1000 \mathrm{rpm}$ for $5 \mathrm{~min}$ and seeding $8 \times 10^{3}$ cells $/ \mathrm{cm}^{2}$ in tissue culture flasks to maintain the cells in the exponential phase. All experiments were carried out on exponentially growing cells. The cell suspensions were seeded into $5 \mathrm{~mL}$ media containing $100 \mathrm{~mm}$ cell culture plates and incubated for approximately $20-24 \mathrm{~h}$ before the experiments in order to reach confluency. In the present study, we performed MTT assay, analysis of cell morphology, growth kinetics assay, clonogenic assay, ROS measurement and caspase 3/7 assay on cells treated by the synthesized compounds.

\subsection{Syntheses}

The protected compounds $\mathrm{H}_{2} \mathrm{~L}^{p-O M e}\left(\mathbf{1}^{P}\right), \mathrm{H}_{2} \mathrm{~L}^{m-O M e}$ $\left(\mathbf{2}^{P}\right)$ and $\mathrm{H}_{2} \mathrm{~L}^{m d}\left(\mathbf{3}^{P}\right)$ were synthesized as reported earlier. $^{19}$

2.3a N-(4-methoxyphenyl)picolinamide $\left(4^{P}\right)$ : To a solution of pyridine-2-carboxylic acid $(2.0 \mathrm{~g}, 0.016$ $\mathrm{mmol})$ in pyridine $(20 \mathrm{~mL})$ was added 4-methoxy aniline $(2.0 \mathrm{~g}, 0.016 \mathrm{mmol})$ and triphenylphosphite $(5.2 \mathrm{~g}$, $0.017 \mathrm{mmol}$ ) while stirring. The resulting mixture was heated to $110^{\circ} \mathrm{C}$ and stirred for $6 \mathrm{~h}$. Excess pyridine was removed under vacuum followed by the addition of $50 \mathrm{~mL}$ dichloromethane. The resulting product was

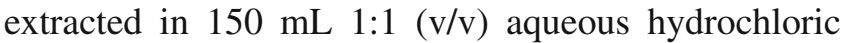
acid. The acidic aqueous extract was neutralised by the addition of solid sodium bicarbonate. The white solid separated was filtered, washed thoroughly with water and air dried. The resulting solid was recrystallized from a saturated solution of compound in methanolwater. Yield: $2.5 \mathrm{~g}(75 \%) .{ }^{1} \mathrm{H}$ NMR $\left(400 \mathrm{MHz}, d_{6}\right.$ DMSO): $\delta 3.73\left(\mathrm{~s}, 3 \mathrm{H}, \mathrm{OCH}_{3}\right), 6.92(\mathrm{~d}, J=8.7 \mathrm{~Hz}, 2 \mathrm{H}$, $\left.\mathrm{H}_{10} \& \mathrm{H}_{12}\right), 7.80\left(\mathrm{~d}, J=8.2 \mathrm{~Hz}, 2 \mathrm{H}, \mathrm{H}_{9} \& \mathrm{H}_{13}\right), 7.6$ (t, $\left.J=5.96 \mathrm{~Hz}, 1 \mathrm{H}, \mathrm{H}_{3}\right), 8.04\left(\mathrm{t}, J=7.7 \mathrm{~Hz}, 1 \mathrm{H}, \mathrm{H}_{4}\right), 8.13$ $\left(\mathrm{d}, J=8.0 \mathrm{~Hz}, 1 \mathrm{H}, \mathrm{H}_{5}\right), 8.71\left(\mathrm{~d}, J=4.1 \mathrm{~Hz}, 1 \mathrm{H}, \mathrm{H}_{2}\right)$, $10.51(\mathrm{~s}, 1 \mathrm{H}, \mathrm{NH}-\mathrm{C}=\mathrm{O}) \mathrm{ppm} .{ }^{13} \mathrm{C}$ NMR $\left(75 \mathrm{MHz}, d_{6^{-}}\right.$ DMSO): $\delta 113.83\left(\mathrm{C}_{10} \& \mathrm{C}_{12}\right), 121.80\left(\mathrm{C}_{5}\right), 122.29\left(\mathrm{C}_{9}\right.$ $\left.\& \mathrm{C}_{13}\right), 1126.80\left(\mathrm{C}_{3}\right), 131.52\left(\mathrm{C}_{8}\right), 138.14\left(\mathrm{C}_{4}\right), 148.44$ $\left(\mathrm{C}_{2}\right), 150.10\left(\mathrm{C}_{6}\right), 155.73\left(\mathrm{C}_{11}\right), 162.10\left(\mathrm{C}_{7}\right), 55.22$ $\left(\mathrm{OCH}_{3}\right)$ ppm. Selected FT-IR bands $\left(\mathrm{KBr}, v \mathrm{~cm}^{-1}\right)$ : $3356(\mathrm{NH}), 1683(\mathrm{C}=\mathrm{O})$.

2.3b $\quad N$-(3-methoxyphenyl)picolinamide $\quad\left(5^{P}\right): \mathrm{A}$ similar procedure with an identical scale was followed for the synthesis of $\mathbf{5}^{P}$. Yield: $2.0 \mathrm{~g}(67 \%) .{ }^{1} \mathrm{H}$ NMR $\left(300 \mathrm{MHz}, d_{6}\right.$-DMSO): $\delta 3.71\left(\mathrm{~s}, 3 \mathrm{H},-\mathrm{OCH}_{3}\right), 6.65(\mathrm{~d}$, $\left.J=7.8 \mathrm{~Hz}, 1 \mathrm{H}, \mathrm{H}_{11}\right), 7.21\left(\mathrm{t}, J=9.1 \mathrm{~Hz}, 1 \mathrm{H}, \mathrm{H}_{12}\right)$, $7.47\left(\mathrm{~d}, J=7.8 \mathrm{~Hz}, 1 \mathrm{H}, \mathrm{H}_{13}\right), 7.56\left(\mathrm{~s}, 1 \mathrm{H}, \mathrm{H}_{9}\right), 7.63$ (t, $\left.J=7.8 \mathrm{~Hz}, 1 \mathrm{H}, \mathrm{H}_{3}\right), 8.02\left(\mathrm{t}, J=7.8 \mathrm{~Hz}, 1 \mathrm{H}, \mathrm{H}_{4}\right)$, $8.11\left(\mathrm{~d}, J=6.8 \mathrm{~Hz}, 1 \mathrm{H}, \mathrm{H}_{5}\right), 8.69(\mathrm{~d}, J=5.9 \mathrm{~Hz}$, $\left.1 \mathrm{H}, \mathrm{H}_{2}\right), 10.55(\mathrm{~s}, 1 \mathrm{H}, \mathrm{NH}-\mathrm{C}=\mathrm{O}) \mathrm{ppm} .{ }^{13} \mathrm{C} \mathrm{NMR}$ (75 MHz, $d_{6}$-DMSO): $\delta 106.56\left(\mathrm{C}_{9}\right), 110.26\left(\mathrm{C}_{13}\right)$, $112.90\left(\mathrm{C}_{11}\right), 123.13\left(\mathrm{C}_{5}\right), 127.53\left(\mathrm{C}_{3}\right), 130.01\left(\mathrm{C}_{12}\right)$, $138.64\left(\mathrm{C}_{4}\right), 140.05\left(\mathrm{C}_{8}\right), 148.70\left(\mathrm{C}_{2}\right), 150.30\left(\mathrm{C}_{6}\right)$, $160\left(\mathrm{C}_{10}\right), 162.99\left(\mathrm{C}_{7}\right), 55.55\left(\mathrm{OCH}_{3}\right)$ ppm. Selected FT-IR bands $\left(\mathrm{KBr}, v \mathrm{~cm}^{-1}\right)$ : $3336(\mathrm{NH}), 1684(\mathrm{C}=\mathrm{O})$. 
2.3c N-(3,4-methylenedioxy benzene carbamoyl)picolinamide $\left(\boldsymbol{6}^{P}\right)$ : A similar procedure with an identical scale was followed for the synthesis of $\mathbf{6}^{P}$. Yield: $2.8 \mathrm{~g}$ (78\%). ${ }^{1} \mathrm{H}$ NMR (300 MHz, $d_{6}$-DMSO): $\delta 5.98(s, 2 \mathrm{H}$, $\left.\mathrm{OCH}_{2}\right), 6.79\left(\mathrm{~d}, J=6.2 \mathrm{~Hz}, 1 \mathrm{H}, \mathrm{H}_{12}\right), 7.15(\mathrm{~d}, J=$ $\left.6.2 \mathrm{~Hz}, 1 \mathrm{H}, \mathrm{H}_{13}\right), 7.53\left(\mathrm{~m}, 1 \mathrm{H}, \mathrm{H}_{3}\right), 7.56\left(\mathrm{~s}, 1 \mathrm{H}, \mathrm{H}_{9}\right)$, $7.95\left(\mathrm{t}, J=5.7 \mathrm{~Hz}, 1 \mathrm{H}, \mathrm{H}_{4}\right), 8.21(\mathrm{~d}, J=5.8 \mathrm{~Hz}$, $\left.1 \mathrm{H}, \mathrm{H}_{5}\right), 8.64\left(\mathrm{~d}, J=4.3 \mathrm{~Hz}, 1 \mathrm{H}, \mathrm{H}_{2}\right), 10.16(\mathrm{~s}$, $\mathrm{NH})$ ppm. ${ }^{13} \mathrm{C}$ NMR $\left(75 \mathrm{MHz}, d_{6}\right.$-DMSO): $\delta 101.09$ $\left(\mathrm{OCH}_{2}\right), 102.32\left(\mathrm{C}_{9}\right), 108\left(\mathrm{C}_{12}\right), 113.35\left(\mathrm{C}_{13}\right), 122.33$ $\left(\mathrm{C}_{5}\right), 126.86\left(\mathrm{C}_{3}\right), 132.76\left(\mathrm{C}_{8}\right), 138.14\left(\mathrm{C}_{4}\right), 143.48$ $\left(\mathrm{C}_{11}\right), 147.08\left(\mathrm{C}_{10}\right), 148.43\left(\mathrm{C}_{2}\right), 149.94\left(\mathrm{C}_{6}\right), 162.21$ $\left(\mathrm{C}_{7}\right) \mathrm{ppm}$. Selected FT-IR bands $\left(\mathrm{KBr}, v \mathrm{~cm}^{-1}\right): 3275$ $(\mathrm{N}-\mathrm{H}), 1654,1650(\mathrm{C}=\mathrm{O})$.

\subsection{Deprotection of compounds $1^{P}-6^{P}$}

2.4a 2,6-Bis(4-hydroxy-benzene-carbamoyl)pyridine: (1). $\mathrm{H}_{2} \mathrm{~L}^{\text {p-OMe }}(1.0 \mathrm{~g}, 0.0026 \mathrm{mmol})$ was dissolved in $40 \mathrm{~mL}$ of dry and degassed $\mathrm{CH}_{2} \mathrm{Cl}_{2}$ and $\mathrm{BBr}_{3}(0.8 \mathrm{~mL}$, $0.0079 \mathrm{mmol})$ was added under the nitrogen atmosphere at $-70^{\circ} \mathrm{C}$. The resulting yellow slurry was stirred for $8 \mathrm{~h}$ at room temperature. The slurry was slowly quenched with the addition of $\mathrm{MeOH}$. Evaporation of the solvent gave an off-white solid which was further recrystallized from methanol. Yield: $0.58 \mathrm{~g}(60 \%) .{ }^{1} \mathrm{H}$ NMR $\left(300 \mathrm{MHz}, d_{6}\right.$-DMSO): $\delta 6.80(\mathrm{~d}, J=8.7 \mathrm{~Hz}$, $\left.4 \mathrm{H}, \mathrm{H}_{10} \& \mathrm{H}_{12}\right), 7.61\left(\mathrm{~d}, J=8.4 \mathrm{~Hz}, 4 \mathrm{H}, \mathrm{H}_{9} \& \mathrm{H}_{13}\right)$, $8.25\left(\mathrm{t}, J=7.5 \mathrm{~Hz}, 1 \mathrm{H}, \mathrm{H}_{4}\right), 8.33(\mathrm{~d}, J=7.5 \mathrm{~Hz}$, $2 \mathrm{H}, \mathrm{H}_{3} \& \mathrm{H}_{5}$ ), 3.98 (broad s, OH), 10.85 (s, 2H, NH$\mathrm{C}=\mathrm{O}) \mathrm{ppm} .{ }^{13} \mathrm{C}$ NMR $\left(75 \mathrm{MHz}, d_{6}\right.$-DMSO): $\delta 139.96$ $\left(\mathrm{C}_{4}\right), 125.33\left(\mathrm{C}_{3} \& \mathrm{C}_{5}\right), 148.97 \quad\left(\mathrm{C}_{2} \& \mathrm{C}_{6}\right), 161.59$ $\left(\mathrm{C}_{7}\right), 129.47\left(\mathrm{C}_{8}\right), 111.82\left(\mathrm{C}_{9} \& \mathrm{C}_{13}\right), 108.10\left(\mathrm{C}_{10} \&\right.$ $\left.\mathrm{C}_{12}\right), 157.68\left(\mathrm{C}_{11}\right)$ ppm. Selected FT-IR bands $(\mathrm{KBr}, v$ $\left.\mathrm{cm}^{-1}\right): 3256(\mathrm{OH}), 3342(\mathrm{NH}), 1662(\mathrm{C}=\mathrm{O})$.

2.4b 2,6-Bis(3-hydroxy-benzene-carbamoyl)pyridine (2): An identical procedure as discussed for $\mathbf{1}$ was followed for the synthesis of 2. Yield: $0.54 \mathrm{~g}(55 \%)$. ${ }^{1} \mathrm{HNMR}\left(300 \mathrm{MHz}, d_{6}\right.$-DMSO): $\delta 6.57 \mathrm{~d}, J=$ $\left.7.8 \mathrm{~Hz}, 2 \mathrm{H}, \mathrm{H}_{11}\right), 7.20\left(\mathrm{t}, J=7.9 \mathrm{~Hz}, 2 \mathrm{H}, \mathrm{H}_{13}\right), 7.29$ $\left(\mathrm{t}, J=8.1 \mathrm{~Hz}, 2 \mathrm{H}, \mathrm{H}_{12}\right), 7.45\left(\mathrm{~s}, 2 \mathrm{H}, \mathrm{H}_{9}\right), 8.20$ $\left(\mathrm{t}, J=7.6 \mathrm{~Hz}, 1 \mathrm{H}, \mathrm{H}_{4}\right), 8.36\left(\mathrm{~d}, J=7.5 \mathrm{~Hz}, 2 \mathrm{H}, \mathrm{H}_{5}\right.$ \& $\mathrm{H}_{3}$ ), 9.73 (broad s, OH), $10.92(\mathrm{~s}, 2 \mathrm{H}, \mathrm{NH}-\mathrm{C}=\mathrm{O}) \mathrm{ppm}$ : ${ }^{13} \mathrm{C}$ NMR $\left(75 \mathrm{MHz}, d_{6}\right.$-DMSO): $\delta 148.97\left(\mathrm{C}_{2} \& \mathrm{C}_{6}\right)$, $129.47\left(\mathrm{C}_{12}\right), 139.96\left(\mathrm{C}_{8}\right), 161.59\left(\mathrm{C}_{7}\right), 125.33\left(\mathrm{C}_{3} \&\right.$ $\left.\mathrm{C}_{5}\right), 108.10\left(\mathrm{C}_{9}\right), 157.68\left(\mathrm{C}_{10}\right), 111.82\left(\mathrm{C}_{11}\right), 139.11$ $\left(\mathrm{C}_{4}\right), 111.53\left(\mathrm{C}_{13}\right)$ ppm; Selected FT-IR bands $(\mathrm{KBr}, v$ $\left.\mathrm{cm}^{-1}\right)$ : $3249(\mathrm{OH}), 3356(\mathrm{NH}), 1685,1664(\mathrm{C}=\mathrm{O})$.

2.4c 2,6-Bis(3,4-dihydroxy-benzene-carbamoyl)pyridine (3): An identical procedure as discussed for $\mathbf{1}$ was followed for the synthesis of 3. Yield: $0.58 \mathrm{~g}$ (57\%). ${ }^{1} \mathrm{H}$ NMR (300 MHz, $d_{6}$-DMSO): $\delta 6.80$ (d, $J=$ $\left.6.3 \mathrm{~Hz}, 2 \mathrm{H}, \mathrm{H}_{12}\right), 7.17\left(\mathrm{~d}, J=6.3 \mathrm{~Hz}, 2 \mathrm{H}, \mathrm{H}_{13}\right), 7.43$ $\left(\mathrm{s}, 2 \mathrm{H}, \mathrm{H}_{9}\right), 8.15\left(\mathrm{t}, J=5.8 \mathrm{~Hz}, 1 \mathrm{H}, \mathrm{H}_{4}\right), 8.38(\mathrm{~d}, J=$ $\left.5.8 \mathrm{~Hz}, 2 \mathrm{H}, \mathrm{H}_{3} \& \mathrm{H}_{5}\right), 8.90$ (broad s, OH), 10.8 (s, 2H, $\mathrm{NH})$ ppm. ${ }^{13} \mathrm{C}$ NMR $\left(75 \mathrm{MHz}, d_{6}\right.$-DMSO): $\delta 108.67$ $\left(\mathrm{C}_{9}\right), 113.05\left(\mathrm{C}_{12}\right), 115.45\left(\mathrm{C}_{13}\right), 125.07\left(\mathrm{C}_{3} \& \mathrm{C}_{5}\right)$, $130.04\left(\mathrm{C}_{8}\right), 139.96\left(\mathrm{C}_{4}\right), 142.58\left(\mathrm{C}_{11}\right), 145.19\left(\mathrm{C}_{10}\right)$, $149.32\left(\mathrm{C}_{2} \& \mathrm{C}_{6}\right), 161.57\left(\mathrm{C}_{7}\right) \mathrm{ppm}$. Selected FT-IR bands $\left(\mathrm{KBr}, v \mathrm{~cm}^{-1}\right): 3167(\mathrm{OH}), 3367(\mathrm{NH}), 1661$ $(\mathrm{C}=\mathrm{O})$.

2.4d N-(4-hydroxyphenyl)picolinamide (4): An identical procedure as discussed for $\mathbf{1}$ was followed for the synthesis of 4 . Yield: $0.38 \mathrm{~g}(58 \%) .{ }^{1} \mathrm{H}$ NMR (300 MHz, $d_{6}$-DMSO): $\delta 6.73\left(\mathrm{~d}, J=8.8 \mathrm{~Hz}, 2 \mathrm{H}, \mathrm{H}_{10}\right.$ $\left.\& \mathrm{H}_{12}\right), 7.64\left(\mathrm{~d}, J=9.5 \mathrm{~Hz}, 2 \mathrm{H}, \mathrm{H}_{9} \& \mathrm{H}_{13}\right), 7.67(\mathrm{t}, 1 \mathrm{H}$, $\left.\mathrm{H}_{4}\right), 8.07\left(\mathrm{t}, J=9.5 \mathrm{~Hz}, 1 \mathrm{H}, \mathrm{H}_{3}\right), 8.15(\mathrm{~d}, J=5.8 \mathrm{~Hz}$, $\left.1 \mathrm{H}, \mathrm{H}_{5}\right), 8.71\left(\mathrm{~d}, J=5.8 \mathrm{~Hz}, 1 \mathrm{H}, \mathrm{H}_{2}\right), 10.41(\mathrm{~s}, 1 \mathrm{H}$, $\mathrm{NH}-\mathrm{C}=\mathrm{O}), 4.54$ (broad, $\mathrm{OH}$ ) ppm. ${ }^{13} \mathrm{C}$ NMR $(75 \mathrm{MHz}$, $d_{6}$-DMSO): $\delta 139.96\left(\mathrm{C}_{4}\right), 125.33\left(\mathrm{C}_{3} \& \mathrm{C}_{5}\right), 148.97$ $\left(\mathrm{C}_{2} \& \mathrm{C}_{6}\right), 161.59\left(\mathrm{C}_{7}\right), 129.47\left(\mathrm{C}_{8}\right), 111.82\left(\mathrm{C}_{9} \& \mathrm{C}_{13}\right)$, $108.10\left(\mathrm{C}_{10} \& \mathrm{C}_{12}\right), 157.68\left(\mathrm{C}_{11}\right)$ ppm. Selected FTIR bands (KBr, $\left.v \mathrm{~cm}^{-1}\right)$ : $3244(\mathrm{OH}), 3299(\mathrm{NH}), 1638$ $(\mathrm{C}=\mathrm{O})$.

2.4e N-(3-hydroxyphenyl)picolinamide (5): An identical procedure as discussed for $\mathbf{1}$ was followed for the synthesis of 5. Yield: $0.36 \mathrm{~g} \mathrm{(55 \% ).}{ }^{1} \mathrm{HNMR}(300 \mathrm{MHz}$, $d_{6}$-DMSO): $\delta 6.49\left(\mathrm{~d}, J=6.7 \mathrm{~Hz}, 1 \mathrm{H}, \mathrm{H}_{11}\right), 7.08$ $\left(\mathrm{t}, J=5.9 \mathrm{~Hz}, 1 \mathrm{H}, \mathrm{H}_{12}\right), 7.19(\mathrm{~d}, J=5.6 \mathrm{~Hz}, 1 \mathrm{H}$, $\left.\mathrm{H}_{13}\right), 7.42\left(\mathrm{~s}, 1 \mathrm{H}, \mathrm{H}_{9}\right), 7.64\left(\mathrm{t}, J=4.7 \mathrm{~Hz}, 1 \mathrm{H}, \mathrm{H}_{3}\right)$, $8.03\left(\mathrm{t}, J=4.7 \mathrm{~Hz}, 1 \mathrm{H}, \mathrm{H}_{4}\right), 8.11(\mathrm{~d}, J=4.5 \mathrm{~Hz}, 1 \mathrm{H}$, $\left.\mathrm{H}_{5}\right), 8.69\left(\mathrm{~d}, 1 \mathrm{H}, \mathrm{H}_{2}\right), 10.41(\mathrm{~s}, 1 \mathrm{H}, \mathrm{NH}-\mathrm{C}=\mathrm{O}) \mathrm{ppm}$. ${ }^{13} \mathrm{C}$ NMR (75 MHz, $d_{6}$-DMSO): $\delta 107.26\left(\mathrm{C}_{9}\right), 110.97$ $\left(\mathrm{C}_{11} \& \mathrm{C}_{13}\right), 122.42\left(\mathrm{C}_{5}\right), 127.10\left(\mathrm{C}_{3}\right), 129.35\left(\mathrm{C}_{12}\right)$, $138.31\left(\mathrm{C}_{4}\right), 139.35\left(\mathrm{C}_{8}\right), 148.39\left(\mathrm{C}_{2}\right), 149.76\left(\mathrm{C}_{6}\right)$, $157.67\left(\mathrm{C}_{10}\right), 162.18\left(\mathrm{C}_{7}\right)$ ppm. Selected FT-IR bands $\left(\mathrm{KBr}, v \mathrm{~cm}^{-1}\right)$ : $3254(\mathrm{OH}), 3339(\mathrm{NH}), 1670(\mathrm{C}=\mathrm{O})$.

2.4f $\quad N-(3, \quad 4-d i h y d r o x y p h e n y l) p i c o l i n a m i d e \quad(6)$ : An identical procedure as discussed for 1 was followed for the synthesis of $\mathbf{6}$. Yield: $0.4 \mathrm{~g}(62 \%) .{ }^{1} \mathrm{H}$ NMR (300 MHz, $d_{6}$-DMSO): $\delta 6.70\left(\mathrm{~d}, J=8.4 \mathrm{~Hz}, 1 \mathrm{H}, \mathrm{H}_{12}\right)$, $7.05\left(\mathrm{~d}, J=8.4 \mathrm{~Hz}, 1 \mathrm{H}, \mathrm{H}_{13}\right), 7.42\left(\mathrm{~s}, 1 \mathrm{H}, \mathrm{H}_{9}\right), 7.70(\mathrm{t}$, $\left.J=5.2 \mathrm{~Hz}, 1 \mathrm{H}, \mathrm{H}_{3}\right), 8.11\left(\mathrm{t}, J=7.3 \mathrm{~Hz}, 1 \mathrm{H}, \mathrm{H}_{4}\right), 8.18$ $\left(\mathrm{d}, J=7.5 \mathrm{~Hz}, 1 \mathrm{H}, \mathrm{H}_{5}\right), 8.64\left(\mathrm{~d}, J=8.8 \mathrm{~Hz}, 1 \mathrm{H}, \mathrm{H}_{2}\right)$ ppm. ${ }^{13} \mathrm{C}$ NMR (75 MHz, $d_{6}$-DMSO): $\delta 102.26\left(\mathrm{C}_{9}\right)$, $104.05\left(\mathrm{C}_{12}\right), 115.20\left(\mathrm{C}_{13}\right), 125.51\left(\mathrm{C}_{5}\right), 127.26\left(\mathrm{C}_{3}\right)$, $129.64\left(\mathrm{C}_{8}\right), 135.54\left(\mathrm{C}_{4}\right), 138\left(\mathrm{C}_{11}\right), 142.11\left(\mathrm{C}_{10}\right)$, $144.25\left(\mathrm{C}_{2}\right), 151.05\left(\mathrm{C}_{6}\right) 153.55\left(\mathrm{C}_{7}\right)$ ppm. Selected 
FT-IR bands $\left(\mathrm{KBr}, v \mathrm{~cm}^{-1}\right): 3144(-\mathrm{OH},-\mathrm{NH}), 1679$ $(\mathrm{C}=\mathrm{O})$.

\subsection{Physical measurements}

The elemental analysis data were obtained from the Elementar Analysensysteme GmbH Vario EL-III instrument. The NMR measurements were done using an Avance Bruker (300 MHz) or Jeol (400 MHz) instruments. The Fourier Transform infrared (FTIR) spectra were recorded using the Perkin Elmer FTIR 2000 spectrometer. The thermal analyses were performed with a Shimadzu DTG-60 instrument in the temperature range of $25-800^{\circ} \mathrm{C}$, at $5^{\circ} \mathrm{C} \mathrm{min}^{-1}$ heating rate under nitrogen atmosphere.

\subsection{Crystallography}

The crystals for compounds $\mathbf{1}, \mathbf{2}, \mathbf{4}, 5$ and $\mathbf{6}$ were grown from methanol either by slow evaporation or by vapour diffusion of diethyl ether. The x-ray diffraction data for $\mathbf{1}, \mathbf{2}, 5$ and $\mathbf{6}$ were collected on an Oxford XCalibur CCD diffractometer whereas for $\mathbf{4}$ on Bruker Kappa Apex-CCD diffractometer equipped with graphite monochromatic $\mathrm{Mo} / \mathrm{K}_{\alpha}$ radition $(\lambda=$ $0.71073 \AA) .{ }^{31,32}$ The structures were solved by the direct methods and refined by full-matrix least-squares refinement techniques on $F^{2}$ using SHLEXL-97 in WinGX module. ${ }^{33,34}$ The non-hydrogen atoms were refined anisotropically. All hydrogen atoms were fixed geometrically with Uiso values of 1.2 and 1.5 times the Uiso values of phenylene carbon atom and phenolic hydrogen atoms, respectively. For compound $\mathbf{5}$ there was scattered electron density around the bromine atom that could not be assigned and resulted into large $R$ value. There were positionally disordered oxygen atoms $\mathrm{O} 4$ and $\mathrm{O} 2$ for compounds $\mathbf{5}$ and $\mathbf{6}$, respectively. These atoms could be located easily and were refined with site occupancy factor (SOF) of 0.5 . This generates compounds 5 and $\mathbf{6}$ with one of its oxygen atom $(\mathrm{O} 4$ and $\mathrm{O} 2$, respectively) being disordered over two positions with $50 \%$ site occupancy. In general, all molecules produced very thin plate-like crystals which diffracted poorly. Due to such a problem, the final $R$ value was quite on the higher side. Detail of the X-ray data collection and structure solution parameters is provided in table 1.

Crystallographic data (without structure factors) for the structure reported in this paper have been deposited with the Cambridge Crystallographic Data Centre (CCDC) as supplementary publication no. CCDC942968-942972. Copies of the data can be obtained free of charge from the CCDC (12 Union Road, Cambridge
CB2 1EZ, UK; Tel.: +44-1223-336408; Fax: +441223-336003; e-mail: deposit@ccdc.cam.ac.uk; website: http://www.ccdc.cam.ac.uk).

\subsection{In vitro cell growth inhibition assay (MTT assay)}

Cells were seeded in 96-well plates at a concentration of $1 \times 10^{4}$ cells/well in $200 \mu \mathrm{L}$ of complete media and incubated for $24 \mathrm{~h}$ at $37^{\circ} \mathrm{C}$ in $5 \% \mathrm{CO}_{2}$ atmosphere to allow for cell adhesion. Stock solutions ( $3 \mathrm{mg} / \mathrm{mL}$ ) of the compounds made in DMSO were filter-sterilized and further diluted upto $11.71 \mu \mathrm{g} / \mathrm{mL}$ in an incomplete media using PBS for treatment against all 5 cell lines. Typically a $100 \mu \mathrm{L}$ solution of compound was added to a $100 \mu \mathrm{L}$ solution of fresh medium in wells to give final concentrations of 1500 $11.71 \mu \mathrm{g} / \mathrm{mL}$. All assays were performed in three independent sets of tests. Control group containing no compound treatment was run in each assay. Following $24 \mathrm{~h}$ exposure of cells to drug, each well was carefully rinsed with $200 \mu \mathrm{L}$ PBS buffer. Cytotoxicity was assessed using MTT (3-[4,5-dimethylthiazol2-yl]-2,5-diphenyltetrazolium bromide). $20 \mu \mathrm{L}$ MTT solution $\left(5 \mathrm{mg} \mathrm{mL}^{-1} \mathrm{dd} \mathrm{H}_{2} \mathrm{O}\right)$ along with $200 \mu \mathrm{L}$ of fresh complete media were added to each well and plates were incubated for $3 \mathrm{~h}$. Following incubation, the medium was removed and the purple formazan precipitate in each well was sterilized in $100 \mu \mathrm{L}$ DMSO. Absorbance was measured using Biotek Synergy HT microplate reader at $540 \mathrm{~nm}$ and percentage (\%) viability was calculated ${ }^{36-38}$ which was directly proportional to metabolic active cell number as:

$\%$ Viability $=$ OD in sample well/OD in control well $\times 100$.

Results expressed as inhibitory concentration $50\left(\mathrm{IC}_{50}\right)$ were obtained by fitting values to trend dose-response curves using the routines provided in Microsoft Excel.

\subsection{Growth kinetics}

T98G cells were seeded at 10000 cells $/ \mathrm{cm}^{2}$ on the cell culture plate and their proliferation kinetics were studied at different incubation times $(24,48$ and $72 \mathrm{~h}$ ) after compounds treatment, following trypsinization and counting the total cells per plate microscopically using a trypan blue dye and hemocytometer (N7-8). ${ }^{35-38}$

\subsection{Clonogenic assay}

Clonogenic assay or colony formation assay is an in vitro cell survival assay based on the ability of a single 


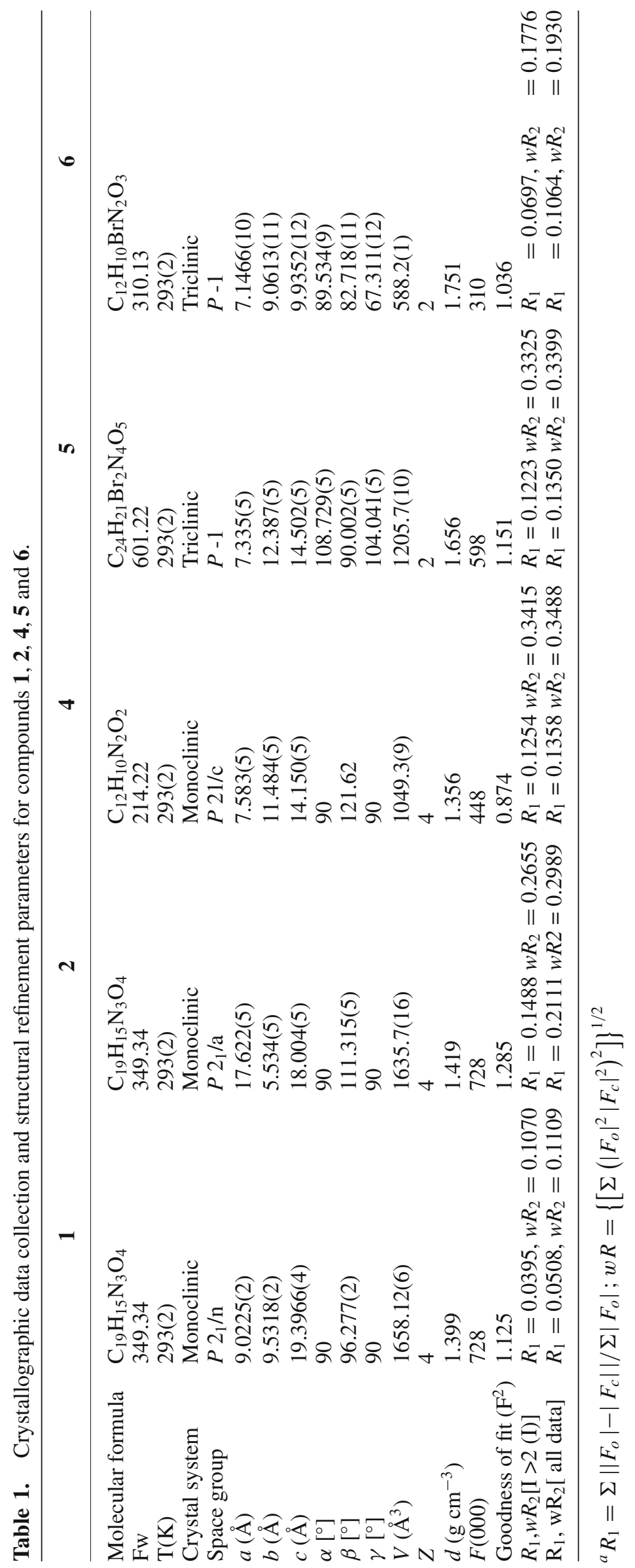


cell to grow into a colony. The colony is defined to consist of at least 50 cells. The assay essentially tests every cell in the population for its ability to undergo 'unlimited' division. ${ }^{35-38}$ Clonogenic assay is the method of choice to determine cell reproductive death after treatment with ionizing radiation, but it can also be used to determine the effectiveness of drug molecules. Only a fraction of seeded cells retains the capacity to produce colonies before or after treatment, cells will be seeded out in appropriate dilutions to form colonies in 1-3 weeks. After harvesting with $0.05 \%$ trypsin, 150 400 (depending on the treatment) cells were plated 10 $14 \mathrm{~h}$ before treatment in DMEM at $37^{\circ} \mathrm{C}$. Cultured cells were treated with doses 20 to $100 \mathrm{ug} / \mathrm{mL}$ of compounds. After the treatment, cells were incubated in dark under humidified, $5 \% \mathrm{CO}_{2}$ atmosphere at $37^{\circ} \mathrm{C}$ for 8-10 days to allow colony formation. Colonies were fixed with methanol and stained with $1 \%$ crystal violet. Colonies of more than 50 cells were counted and the surviving fraction (SF) was calculated. Clonogenic survival curves were constructed from three independent experiments by least-squares regression fitting averaged survival levels.

\subsection{Intracellular ROS measurement}

The fluorochrome probe DCFH-DA was used to measure ROS. The non-fluorescent compound DCFH-DA penetrates into the cell and is cleaved by intracellular esterase, resulting in the formation of DCFH, the oxidation of which (due to oxidative stress) generates the fluorescent compound DCF. Thus, the DCF fluorescence represents the rate and quantity of ROS produced. After treatment with compounds, T98G cells were incubated in fresh media with $10 \mu \mathrm{M}$ DCFH-DA at $37^{\circ} \mathrm{C}$ for 30 minutes and washed twice with PBS and the fluorescence measured using plate reader with excitation at $485 \mathrm{~nm}$ and emission at $528 \mathrm{~nm}$. Average ROS production (relative to level of untreated controls) was calculated from four individual wells in at least three independent plates. Mean fluorescence intensity (MFI) was calculated after correction for autofluorescence.

\subsection{Caspase activity assay}

Following treatments T98G cells were subjected to Caspase 3/7 activity measurement with Caspase-Glo assay kit after 24 hour of incubation. Briefly, the plates containing cells were removed from the incubator and allowed to equilibrate to room temperature for $30 \mathrm{~min}$ utes. $100 \mu \mathrm{l}$ of Caspase-Glo reagent was added to each well, the content of well was gently mixed with a plate shaker at 300-500 rpm for 30 seconds. The plate was then incubated at room temperature for 2 hours. The luminescence of each sample was measured in a platereading luminometer. The experiments were performed in triplicate and repeated on two separately-initiated cultures.

\subsection{Micronucleus assay}

The in vitro micronucleus (MN) assay is an attractive tool for measuring genotoxicity. For measuring micronucleus, T98G cells were treated by compound under similar conditions as used for growth kinetics and clonogenic assay. After treatment, cell cultures were grown for $24 \mathrm{~h}$ to allow chromosomal damage to lead to the formation of micronuclei in bi- or multinucleated interphase cells. Air-dried slides containing acetic acidmethanol $(1: 3 \mathrm{~V} / \mathrm{V})$ fixed treated cells were stained with Hoechst-33342 (10 $\mu \mathrm{g} / \mathrm{mL}$ in 0.1 M PBS), disodium phosphate $(0.45 \mathrm{M})$ buffer containing $0.05 \%$ Tween20 detergent. Slides were examined under the fluorescence microscope using an UV excitation filter. Fluorescent nuclei were visualized using a blue emission filter. Cells containing micronuclei were counted from $>1000$ cells. The fraction of cells containing micronuclei, called the M-fraction (\%) or MN frequency was calculated as follows:

$$
\mathrm{M}-\text { fraction }(\%)=\mathrm{Nm} / \mathrm{Nt} \times 100
$$

where $\mathrm{Nm}$ is the number of cells with micronuclei and $\mathrm{Nt}$ is the total number of cells analyzed. Since, micronuclei formation is linked to cell proliferation, micronuclei frequencies were normalized with respect to the cell numbers.

\subsection{In silico pharmacokinetic screening}

To evaluate pharmacokinetic profile descriptors such as cLog P (octanol/water partition coefficient) and Log S (water solubility) were calculated using the Osiris Property Explorer on-line system. ${ }^{39}$ The molecules were submitted to in silico ADMET (absorption, distribution, metabolism, excretion, and toxicity) screening using the Osiris program. Values of drug-likeness are based on the occurrence frequency of each fragment of the molecule in commercial drugs while the drug-score evaluates the molecules potential to qualify for a drug and is related to topological descriptors, fingerprints of molecular drug-likeness, structural keys and other properties such as cLog P and molecular mass. ${ }^{40,41}$ in silico theoretical safety analysis was also evaluated by Osiris software, score 1 means drug is safe and score 
$<1$ means drug molecule is theoretically toxic for the use. The pharmacokinetic profile, important for a good oral bioavailability of a molecule, was also evaluated according to the Lipinski's 'rule-of-five' by using catalyst and chemaxon software, which analyses features that a drug should present to allow the absorption and permeation across the membranes and states molecular weight $<500$ daltons (Da), calculated octanol/water partition coefficient (cLog P) $<5$, number of hydrogenbond acceptors (nHba) $<10$, and number of hydrogenbond donors (nHbd) $<5$, as well as a fifth rule added later, which infers the number of rotatable bonds $<10$.

\subsection{Statistical analysis}

Data is expressed as a mean $\pm \mathrm{SD}$. Statistical analysis was performed by student student's t-test. Results were considered significant when $P<0.05$.

\section{Results and Discussion}

\subsection{Chemistry}

This work utilizes a series of pyridine-amide based compounds appended with either phenol or catechol groups for their pharmacological properties. ${ }^{42}$ These compounds are categorised in two classes: class one consists of bis-amide compounds $\mathbf{1}^{P}-\mathbf{3}^{P}$ and $\mathbf{1 - 3}$; whereas class two constitutes mono-amide analogues $\mathbf{4}^{P}-\mathbf{6}^{P}$ and 4-6. The protected compounds $\mathbf{1}^{P}-\mathbf{6}^{P}$ were synthesised by the coupling of respective pyridinecarboxylic acid with the required amine (3-methoxy aniline, 4-methoxy aniline or 3,4-methylenedioxy aniline) using $\mathrm{P}(\mathrm{OPh})_{3}$. These protected compounds on treatment with boron tribromide provided the desired compounds with free phenol or catechol groups (scheme 1). It is important to mention here that some of these molecules were found to firmly chelate transition metal ions; ${ }^{19}$ and therefore, likely to have strong potential to interact with biologically relevant metal ions. In addition, the presence of amide and phenol/catechol groups in the resultant coordination complexes were demonstrated to exhibit strong intra as well as intermolecular hydrogen bonding $(\mathrm{H}-\text { bonding })^{19}$ and such features depict their importance to adhere to cell membrane and/or other biological surfaces.

All protected and deprotected compounds were characterized by various spectroscopic methods. The infrared spectra of compounds $\mathbf{1}^{P}-\mathbf{6}^{P}$ show $v_{\mathrm{N}-\mathrm{H}}$ and $v_{\mathrm{C}=\mathrm{O}}$ stretching frequencies in the range of 3274$3356 \mathrm{~cm}^{-1}$ and $1654-1684 \mathrm{~cm}^{-1}$, respectively. The

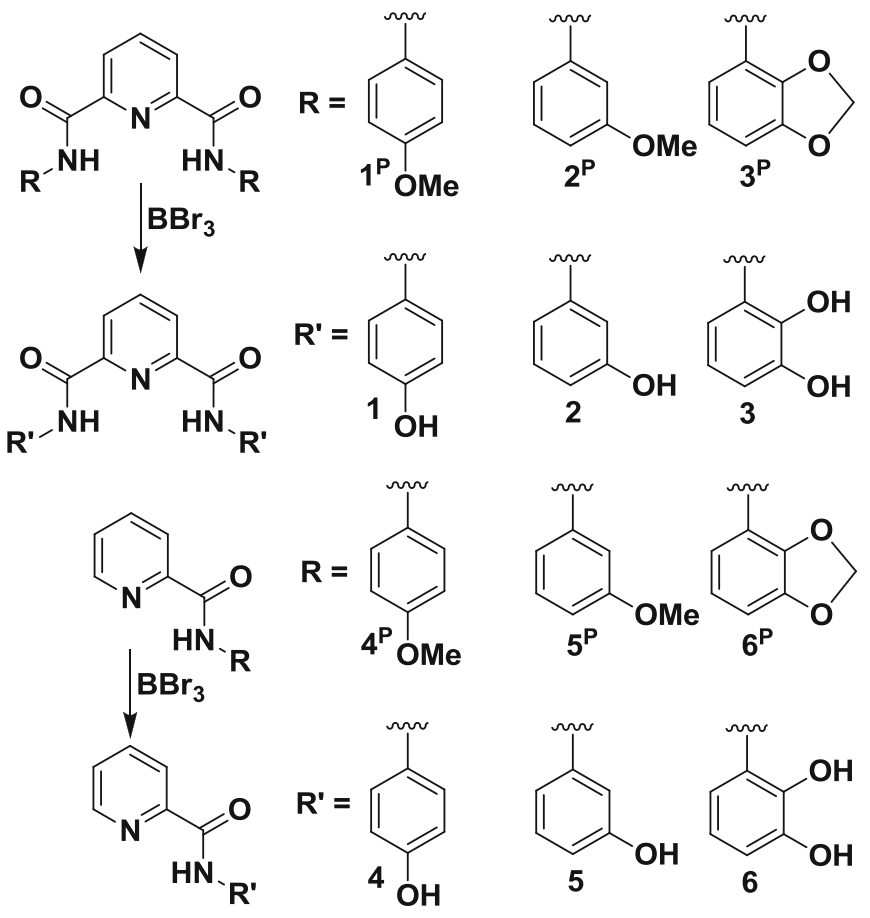

Scheme 1. Synthetic procedure adopted for the protected, $\mathbf{1}^{P}-\mathbf{6}^{P}$ and deprotected compounds, $\mathbf{1 - 6}$.

$v_{\mathrm{N}-\mathrm{H}}$ and $v_{\mathrm{C}=\mathrm{O}}$ stretches for the deprotected compounds, 1-6, were observed in the range of $3300-3367 \mathrm{~cm}^{-1}$ and $1662-1679 \mathrm{~cm}^{-1}$, respectively (table $\mathrm{S} 1$; supporting information). The deprotected compounds show redshifted $v_{\mathrm{C}=\mathrm{O}}$ stretching frequencies than their protected analogues. In addition, the resultant phenolic groups now show $v_{\mathrm{O}-\mathrm{H}}$ in the range of $3144-3253 \mathrm{~cm}^{-1}$ which is significantly red-shifted than the gas-phase phenol suggesting possible $\mathrm{H}$-bonding in all molecules. All protected as well as deprotected compounds were thoroughly characterized by the ${ }^{1} \mathrm{H}$ and ${ }^{13} \mathrm{C}$ NMR spectroscopy (figures S1-S12; tables S2 and S3; supporting information). The ${ }^{1} \mathrm{H}$ NMR spectra of all protected compounds display features for $-\mathrm{NH} ; \mathrm{H}_{\text {pyridine }} ; \mathrm{H}_{\text {arene }}$; $-\mathrm{OCH}_{3}$ or $-\mathrm{OCH}_{2} \mathrm{O}-$ groups. After deprotection with $\mathrm{BBr}_{3}$, the resonances for $-\mathrm{OCH}_{3}$ or $-\mathrm{OCH}_{2} \mathrm{O}-$ groups disappeared and the remaining ring protons were found to appear slightly up-field. In addition, phenol or catechol protons were observed as broad resonances which disappeared on deuterium exchange.

To gain insight about the solid-state conformation, all compounds were characterized by the single crystal diffraction studies (figure 1). Out of six deprotected molecules, two compounds $\mathbf{5}$ and $\mathbf{6}$ could only be crystallized as their $\mathrm{HBr}$ salt with the aid of one equivalent of $\mathrm{HBr}$ thus resulting in the formation of pyridinium ion. The compounds $\mathbf{1}$ and $\mathbf{2}$ show the presence of strong hydrogen bond ( $\mathrm{H}-$ bond) between both $\mathrm{N}-\mathrm{H}$ groups to that of central $\mathrm{N}_{\text {pyridyl }}$ atom. Such 

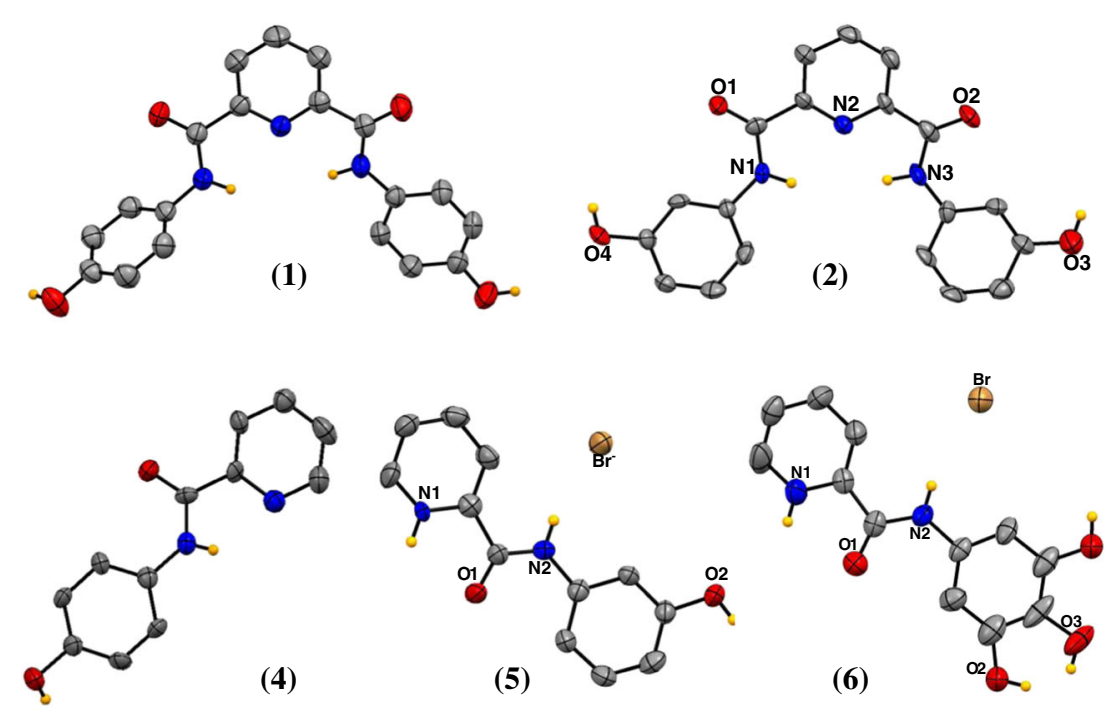

Figure 1. Molecular structures of compounds 1, 2, 4, 5 and 6 with partial numbering scheme (Thermal ellipsoids are drawn at $50 \%$ probability level whereas only phenolic and amidic hydrogen atoms are shown for clarity).

$\mathrm{N}-\mathrm{H} . . \mathrm{N}_{\text {pyridyl }}$ interactions resulted in the stabilization of a single confirmation where two appended phenolic rings are geometrically locked. For both $\mathbf{1}$ and $\mathbf{2}$, the $\mathrm{N}_{\text {amide }} \ldots \mathrm{N}_{\text {pyridyl }}$ heteroatom separation was between $2.630-2.725 \AA$; suggesting strong $\mathrm{H}$ - bond. For mono-amide compounds, two arene rings are almost co-planar to each other as revealed by a small angle $\left(2.66^{\circ}\right.$ for 5 ; $3.70^{\circ}$ for $\mathbf{6}$; and $7.33^{\circ}$ for 4$)$. A somewhat similar situation was observed for compound $\mathbf{2}$ as the aromatic rings were marginally out-of-plane (ca. $6.0^{\circ}$ and ca. $9.4^{\circ}$ ). In contrast, the para-phenolic rings were significantly out-of-plane with respect to the central pyridine ring for bis-amide compound 1 (angles being ca. $15^{\circ}$ and ca. $70^{\circ}$ ). Notably, all these molecules are equipped with $\mathrm{H}$-bond donor $-\mathrm{OH}$ groups and $\mathrm{H}$ bond acceptors $\mathrm{O}_{\text {amide }}$ groups and thus self-assemble into interesting pattern-based networks via intermolecular $\mathrm{H}$ - bonds. Compound $\mathbf{3}$ was also characterized crystallographically and showed the proposed structure. However, poor crystal quality and severe disorders did not allow accurate structure solution and therefore the molecular structure is displayed in figure S13 (supplementary information).

To understand the thermal stability and decomposition profile, the thermogravimetric analysis (TGA) were performed on all six deprotected compounds (figure S14). TGA plots for three bis-amide compounds (1-3) show 5-8\% weight loss in the temperature range of $30-200^{\circ}$ C. Such a weight loss corresponded to the release of lattice solvent molecules. TGA analysis revealed that deprotected bis-amide compounds $\mathbf{1 - 3}$ are thermally stable. In particular, the temperature of melting $\left(\mathrm{T}_{m}\right)$ for 1, 2 and $\mathbf{3}$ was found to be 240, 302 and $275^{\circ} \mathrm{C}$, respectively. In contrast, temperature of melting $\left(\mathrm{T}_{\mathrm{m}}\right)$ for mono-amide molecules $\mathbf{4 , 5}$ and $\mathbf{6}$ was found to be 140,167 and $135^{\circ} \mathrm{C}$, respectively (figure $\mathrm{S} 13$ ). Therefore, thermal studies display lower thermal stability of mono-amide compounds than that of bis-amide analogues.

\subsection{Pharmacology}

3.2a Inhibitory effects of compounds on cancer and normal cells: $\mathrm{The}_{\mathrm{IC}}$ values of all compounds on the T98G brain cancer, H-460 lung cancer, SNU-80 thyroid cancer, non-malignant HEK kidney and non-malignant MRC-5 lung cells were evaluated and the results are presented in table 2 . The MTT cell proliferation assay has been widely accepted as a reliable method to measure the cell proliferation rate and conversely when metabolic events lead to apoptosis or necrosis. The data obtained by the MTT assay show that all compounds have inhibitory effects on the growth of cancer cells in a dose-dependent manner. MTT was reduced by viable cells to coloured formazan via metabolic dehydrogenase enzyme and has been used for chemo and radiosensitivity test. All compounds inhibited the growth of T98G, H-460, SNU-80, HEK and MRC-5 cells, with their $\mathrm{IC}_{50}$ values ranging from 20.55 to $187.35 \mu \mathrm{g} / \mathrm{mL}$ $(52.9$ to $873.8 \mu \mathrm{M})$. However $\mathbf{3}^{P}, \mathbf{2}, \mathbf{3}$ and $\mathbf{6}$ are highly active $\left(\mathrm{IC}_{50}<100 \mu \mathrm{M}\right)$ against brain cancer cell line and showed very less cytotoxicity on non-malignant HEK and MRC-5 cell lines, therefore we selected these four compounds for further experiments on brain cancer cells (table 2). 
Table 2. $\mathrm{IC}_{50}$ values $(\mu \mathrm{g} / \mathrm{mL}, \mu \mathrm{M})$ evaluated from MTT assay on H-460 (lung cancer), T98G (brain cancer), SNU-80 (thyroid cancer), HEK (non-malignant embryonic kidney) and MRC-5 (non-malignant lung fibroblast) cells treated with compounds $\mathbf{1}^{P}-\mathbf{6}^{P}$ and 1-6 for $24 \mathrm{~h}$. Results are given as Mean $( \pm \mathrm{SD}), n=3$. Negative control cell group were treated with medium only and positive control cell population is treated with anticancer drug actinomycin $\mathrm{D}$ (Act-D).

\begin{tabular}{|c|c|c|c|c|c|}
\hline \multirow[t]{3}{*}{ S. No. } & \multicolumn{5}{|c|}{$\mathrm{IC}_{50} \mu \mathrm{g} / \mathrm{mL}( \pm \mathrm{SD}), \mu \mathrm{M}$} \\
\hline & \multicolumn{3}{|c|}{ Malignant Cell Lines } & \multicolumn{2}{|c|}{ Non-malignant cell Lines } \\
\hline & T98G & H-460 & SNU & HEK & MRC-5 \\
\hline $\mathbf{1}^{P}$ & $37.93( \pm 5.5), 100.6$ & $63.16( \pm 4.4), 167.3$ & $43.73( \pm 4.6), 115.9$ & $118.37( \pm 9.0), 313.7$ & $89.54( \pm 13.4), 237.4$ \\
\hline $2^{P}$ & $35.76( \pm 6.7), 94.6$ & $70.72( \pm 4.9), 187.5$ & $39.04( \pm 2.8), 103.5$ & $153.18( \pm 10.1), 406.3$ & $92.39( \pm 11.5), 245$ \\
\hline $3^{P}$ & $32.42( \pm 6.2), 80$ & $59.27( \pm 3.0), 149.34$ & $37.49( \pm 4.9), 92.5$ & $68.74( \pm 8.9), 169.6$ & $139.44( \pm 31.0), 344.1$ \\
\hline $4^{P}$ & $111.03( \pm 14.0), 486.8$ & $145.21( \pm 13.1), 636.8$ & $123.00( \pm 7.9), 539.4$ & $152.87( \pm 16.7), 670.1$ & $152.46( \pm 16.2), 668.4$ \\
\hline $\mathbf{5}^{P}$ & $112.21( \pm 15.2) 492.1$ & $82.41( \pm 6.3), 361.4$ & $105.58( \pm 6.2), 462.7$ & $166.30( \pm 14.5), 729.3$ & $117.22( \pm 11.6), 514.1$ \\
\hline $6^{P}$ & $103.05( \pm 45.1), 425.8$ & $69.49( \pm 6.7), 287.1$ & $78.52( \pm 12.0), 324.3$ & $183.85( \pm 16.7), 759.5$ & $125.18( \pm 7.3), 516.9$ \\
\hline 1 & $45.41( \pm 13.3), 130$ & $33.13( \pm 5.3), 94.92$ & $67.73( \pm 6.6), 194.06$ & $116.57( \pm 6.4), 333.8$ & $96.92( \pm 10.6), 277.0$ \\
\hline 2 & $23.06( \pm 2.9), 66.07$ & $47.91( \pm 3.7), 137.27$ & $39.01( \pm 4.2), 111.7$ & $118.25( \pm 11.6), 338.8$ & $62.96( \pm 6.2), 180.4$ \\
\hline 3 & $20.55( \pm 3.6), 52.9$ & $62.38( \pm 2.3), 163.7$ & $21.30( \pm 3.8), 55.9$ & $73.97( \pm 5.6), 194.1$ & $61.84( \pm 1.5), 162.3$ \\
\hline 4 & $51.92( \pm 14.2), 242.5$ & $70.89( \pm 3.7), 331.2$ & $56.63( \pm 9.3), 264.6$ & $175.55( \pm 19.1), 820.3$ & $123.53( \pm 10.3), 577.1$ \\
\hline 5 & $50.86( \pm 1.6), 237.6$ & $85.11( \pm 8.7), 397.7$ & $58.93( \pm 6.9), 275.2$ & $187.35( \pm 25.9), 873.8$ & $185.81( \pm 17.3), 864.4$ \\
\hline 6 & $24.5( \pm 4.9), 106.5$ & $69.50( \pm 10.5), 302.1$ & $31.97( \pm 2.8), 139$ & $92.473( \pm 10.5), 402$ & $99.38( \pm 10.4), 432$ \\
\hline Act-D & $29.3( \pm 6.1), 23.34$ & - & $25.53( \pm 7.1), 20.34$ & $15.34( \pm 5.9), 12.22$ & - \\
\hline
\end{tabular}

- Not tested

Importantly, out of twelve samples, compounds $\mathbf{3}^{P}, \mathbf{2}$, 3 and 6 were found to inhibit 50\% T98G brain cancer cell growth in the range from 20.55 to $32.42 \mu \mathrm{g} / \mathrm{mL}$ after $24 \mathrm{~h}$ of treatment. Compounds 2, 3 and $\mathbf{6}$ showed potent inhibitory activity as compared to positive control group treated with actinomycin D (Act-D) on brain cancer cells. However, Act-D itself is highly toxic on normal HEK cells. The results show that the present compounds were less cytotoxic to non-malignant normal HEK and MRC-5 cells at moderate concentrations $\left(187.5-11.71 \mu \mathrm{g} / \mathrm{mL}\right.$ ) (table 2). The $\mathrm{IC}_{50}$ values of compounds for MRC-5 cells were in the range from 61.84 to $185.81 \mu \mathrm{g} / \mathrm{mL}$. The results indicate that $\mathbf{3}^{P}, \mathbf{2}, \mathbf{3}$ and 6 inhibit T98G cancer cell growth which may be due to either growth arrest or cell death. Overall, these results clearly demonstrate that the compounds $\mathbf{3}^{P}, \mathbf{2}, \mathbf{3}$ and $\mathbf{6}$ effectively sensitize T98G cells in a dose dependent manner, which may be by increasing the mitotic (linked to cytogenetic damage) or interphase (apoptosis) cell death. We further performed growth kinetics assay, clonogenic assay, ROS measurement assay and Caspase 3/7 activity in treated T98G cells to confirm growth inhibition, clonogenic inhibition, oxidative stress and apoptosis, respectively.

3.2b Growth Kinetics: Growth kinetics of the T98G cells is shown in figure 2. Data obtained by growth kinetics assay show that the compounds $3^{P}, 2, \mathbf{3}$ and $\mathbf{6}$ have an inhibitory effect on T98G cells that is dependent on dose and incubation time. The culture cells were treated at 11.71 to $187.50 \mu \mathrm{g} / \mathrm{mL}$ concentration of compounds and control drug, Act-D. Cell suspensions were made in media layers of $4 \mathrm{~mm}$ thickness in 6 well plates. Notably, treatment of cells with compounds $\mathbf{3}^{P}, \mathbf{2}, \mathbf{6}$ and Act-D showed less effect than those exposed to compound $\mathbf{3}$ after $24 \mathrm{~h}$ of treatment. The maximum effect was seen after exposure to compounds 3 inhibiting the cell growth from 47 to $93 \%$ at $24 \mathrm{~h}$ at all concentrations. Whereas in case of compound $\mathbf{6}$, exposure on T98G cells led to $45-87 \%$ cell death and their viability was 12.47 and $55.68 \%$ at 24 and $72 \mathrm{~h}$, respectively. However, compound $\mathbf{6}$ showed the incubation time dependent effect on the growth of T98G cells and having maximum inhibitory effect at $72 \mathrm{~h}$ of incubation when compared with Act-D and other cases. In essence, compounds $\mathbf{3}^{P}, \mathbf{2}, \mathbf{3}$ and $\mathbf{6}$ inhibited the growth of T98G cells in a dose and incubation dependent manner. Growth pattern and density of T98g cells were also affected after treatment (figure 3). These experiments indicate that the present compounds inhibit T98G cancer cell growth which may be due to either growth arrest or cell death.

3.2c Clonogenic Assay: Figure 4 shows the effect of selected compounds on the colony forming capacity of T98G cells. The clonogenic assay was employed to confirm the colony formation inhibition due to treatment. Only a fraction of seeded cells retains the capacity to produce colonies after cytotoxic drug treatment. Clonogenic assay or colony formation assay is an in-vitro assay based on the ability of a single cell to grow into a colony. This in-vitro clonogenicity method has been 


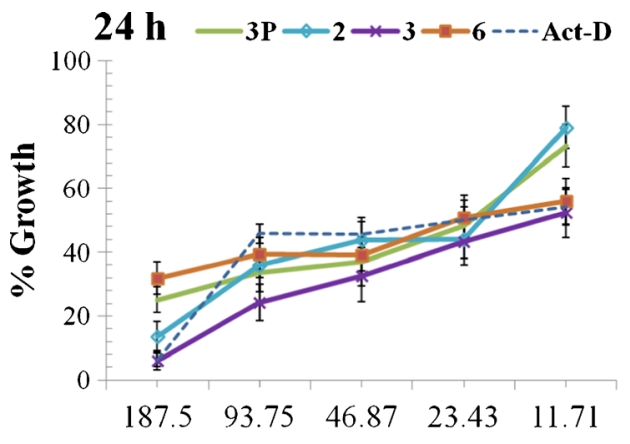

Concentration $(\mu \mathrm{g} / \mathrm{mL})$

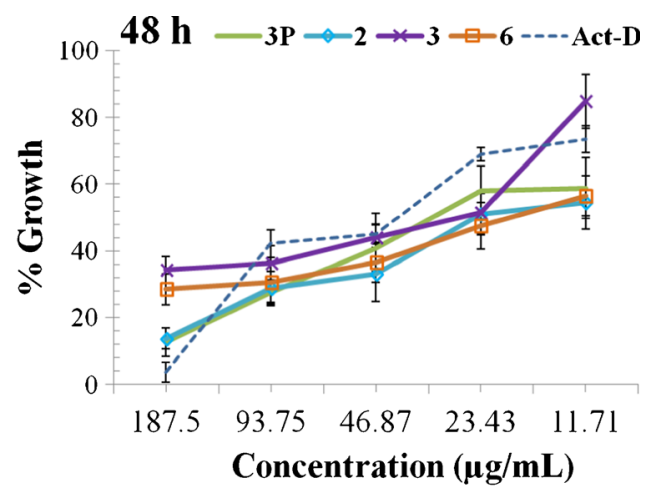

Concentration $(\boldsymbol{\mu g} / \mathrm{mL})$

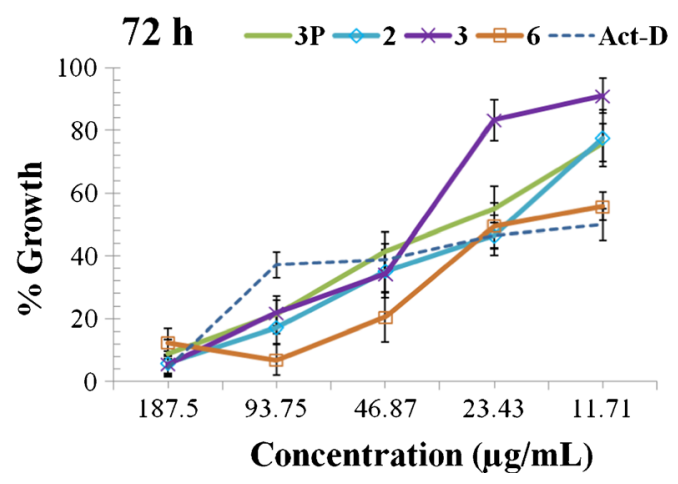

Figure 2. Growth kinetics of T98G cells at 24, 48 and $72 \mathrm{~h}$ after treatment with compounds $\mathbf{3}^{P}, \mathbf{2}, \mathbf{3}$ and $\mathbf{6}$ at $11.71-187.5 \mu \mathrm{g} / \mathrm{mL}$ concentrations. Untreated cells were taken as control and all values are given as mean $( \pm \mathrm{SD})$ of three independent experiments, $n=3$.
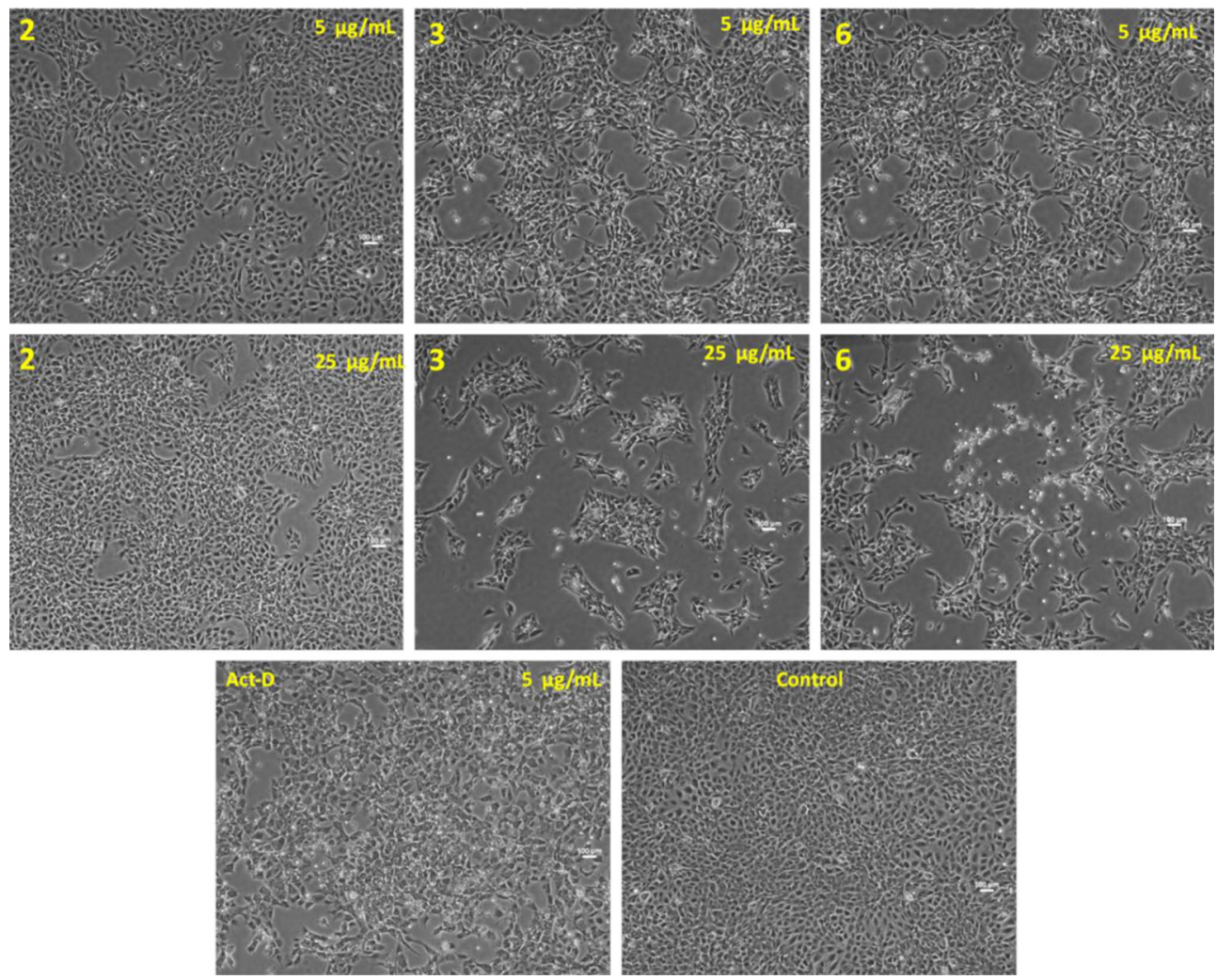

Figure 3. The bright field images of $\mathrm{T} 98 \mathrm{G}$ cells at 1 day after treatment with 5 and $25 \mu \mathrm{g} / \mathrm{mL}$ of compound $\mathbf{2}, \mathbf{3}$ and $\mathbf{6}$. Control cell group were treated with medium only and positive control cell population is treated with $5 \mu \mathrm{g} / \mathrm{mL}$ anticancer drug actinomycin D (Act-D). All scale bars are $100 \mu \mathrm{m}$. 


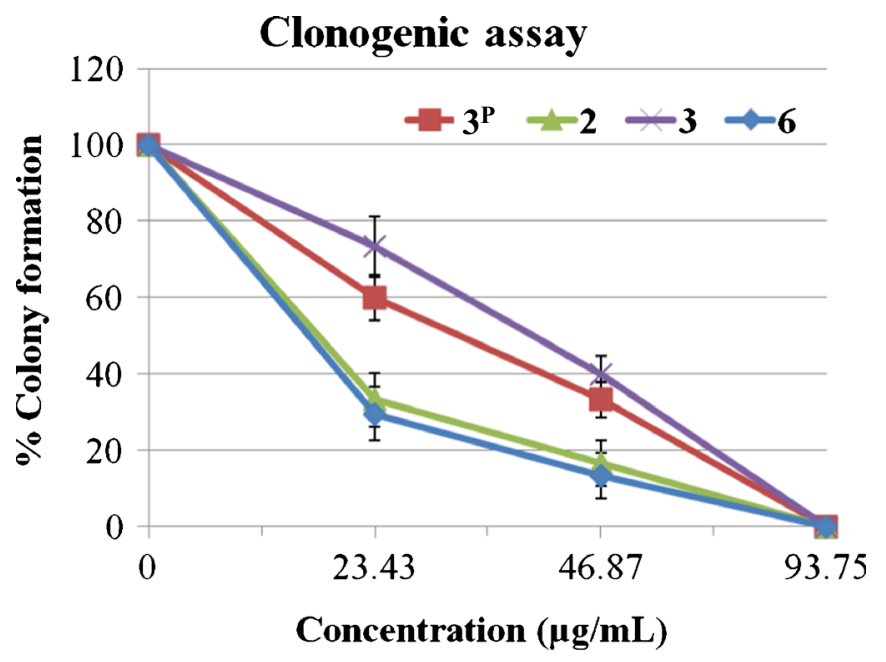

Figure 4. Effect of compounds $3^{P}, \mathbf{2}, \mathbf{3}$ and $\mathbf{6}$ on colony forming capacity or clonogenic survival of exponentially growing $\mathrm{T} 98 \mathrm{G}$ cell lines studied by clonogenic assay at 11.71-93.75 $\mu \mathrm{g} / \mathrm{mL}$ concentrations. Data presented are mean values from three independent observations, $n=3$.

recognized as a valid surrogate assay for tumor growth in vivo. It was observed as the compound concentration increases; the treatment enhances cell death and inhibits the colony formation capability of the T98G cell population. Clonogenic assay shows the effect of compounds $3^{P}, \mathbf{2}, \mathbf{3}$ and $\mathbf{6}$ on the colony forming capacity and survival of exponentially growing T98G cells. It was seen that the survival fraction of T98G cells was drastically decreased after treatment with compounds (figure 4). Importantly, treatment with compounds $\mathbf{3}^{P}, \mathbf{2}$, $\mathbf{3}$ and $\mathbf{6}$ enhances the cell death and also inhibits colony formation capability in the $\mathrm{T} 98 \mathrm{G}$ cell population in a concentration dependent manner. Survival fraction of T98G cells declined on treatments with different concentration (93.75-23.43 $\mu \mathrm{g} / \mathrm{mL}$ ) which is evident by the reduction in the number of colonies formation. Even low dose $(23.43 \mu \mathrm{g} / \mathrm{mL})$ of compounds $\mathbf{3}^{P}, \mathbf{2}, \mathbf{3}$ and 6 showed significant decline in the \% colony survival which was $33.33,60.0,29.66$, and 73.33 , respectively. A drastic decline in the $\%$ colony survival was observed on exposure to higher concentration $(46.87 \mu \mathrm{g} / \mathrm{mL})$ of compounds $3^{P}, \mathbf{2}, \mathbf{3}$ and $\mathbf{6}$. Notably, compounds $\mathbf{2}$ and $\mathbf{6}$ exhibit higher inhibitory effect on colony formation of T98G cells, at all doses. Compound $\mathbf{6}$ shows maximum inhibition at \% colony survival 29.66, 13.33 and 0 on exposure with 23, 46 and $93 \mu \mathrm{g} / \mathrm{mL}$ of doses, respectively. Such outcome reflects the significant inhibitory effect on colony formation capabilities of brain cancer cells at all dosages.

3.2d ROS detection in cells: Reactive oxygen species (ROS) measurement of selected compounds on treatment with T98G brain cells is shown in figure 5 . The decrease in MTT formazen due to growth inhibition and increase in clonogenic inhibition might be induced by increased oxidative stress that would compromise the survival leading to cell death in T98G cells. Therefore to determine if treatment enhanced steady state of oxidative stress in malignant cells, cells were labelled with the oxidation sensitive probe (DCFDA) that is capable of being oxidized to fluorescent product (DCF) by ROS. The fluorescence was measured using plate reader with excitation at $485 \mathrm{~nm}$ and emission at $528 \mathrm{~nm}$. Mean fluorescence intensity (MFI) was calculated after correction for auto-fluorescence. We found that the compounds $3^{P}, \mathbf{2}, \mathbf{3}, \mathbf{6}$ and Act-D enhanced ROS production at $24 \mathrm{~h}$ inside the T98G cells. Treatment by compounds $3^{P}, 2,3,6$ and Act-D increases the DCF fluorescence by $232.1 \%$ (MFI-162.5), $188.5 \%$ (MFI-132), $212.8 \%$ (MFI-149), 239.2\% (MFI-167.5) and 241\% (168.75), respectively at concentration $2.92 \mu \mathrm{g} / \mathrm{mL}$ in T98G cells as compared to untreated control (MFI-70). However, more significant change in ROS production was observed in cells treated with $1.46 \mu \mathrm{g} / \mathrm{mL}$ concentration of compounds when compared with Act-D (positive control). Interestingly, liquid holding conditions had no influence on oxidative stress in any of the cell line studied, as the DCF fluorescence of untreated cells was similar in PBS and growth media (MFI in PBS, $\mathrm{DCF}=75$; MFI in growth media, $\mathrm{DCF}=70$ ).

3.2e Caspase 3/7 activity: To assess the effect of compounds on the activity of Caspase $3 / 7$ in brain cancer cells, the human T98G cell line were treated with different doses of compounds. It is widely assumed that

\section{Reactive Oxygen Species}

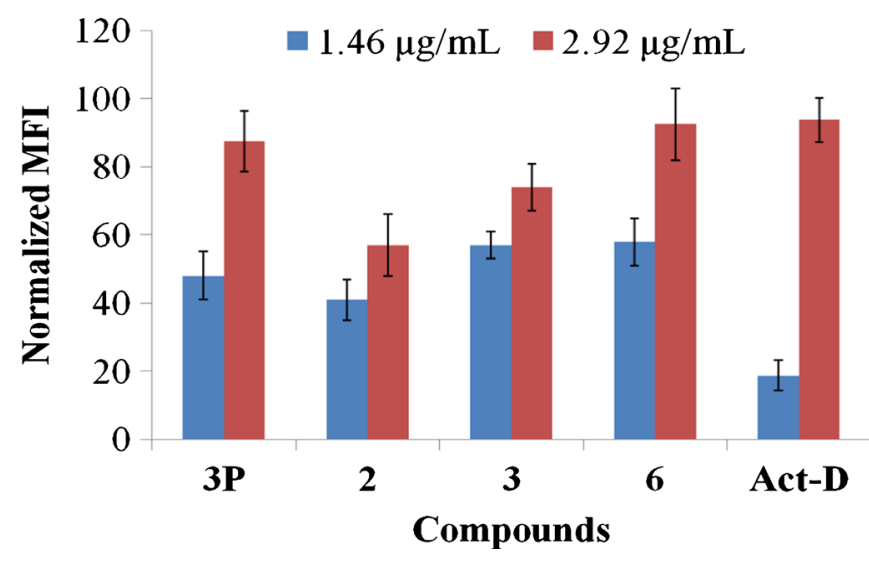

Figure 5. Effect of compounds $\mathbf{3}^{P}, \mathbf{2}, \mathbf{3}$ and $\mathbf{6}$ on the reactive oxygen species (ROS) level in T98G cell lines. ROS values (in MFI, mean florescence intensity) presented are mean $\pm \mathrm{SD}(n=3)$. 
the apoptotic death of mammalian cells is closely associated with the activation of Caspases. Caspase- 3 and -7 play a crucial role as early apoptosis biochemical markers in mammalian cells. Caspase-Glo@ $3 / 7$ assay uses a luminogenic substrate containing the DEVD sequence which is selective for caspase-3 and -7. The caspases activity in both non-treated and treated cancer cells were measured after $24 \mathrm{~h}$ and the result are shown in figure 6.

Caspase activity level detected in non-treated control cells corresponded to the portion of apoptotic cells present in the naturally growing population due to natural aging. In treated cells, activities of Caspase- 3 and -7 increased from 1.3-2.0 fold $(P<0.05)$ over basal levels signifying an activation of these caspases in T98G cancer cells treated with the compounds. Notably, treatment with 3 and $\mathbf{6}$ shows more than two-fold increase in Caspase activity when compared with untreated control. In general, the results show that these compounds are inducing apoptosis in T98G cell population in dose dependent manner at $24 \mathrm{~h}$ after treatment.

3.2f Genotoxicity against brain cancer cells: In recent years, the in-vitro micronucleus (MN) assay has become an attractive tool for measuring genotoxicity by any physical and chemical agents, because of its capacity to detect clastogenic and aneugenic events, simplicity of scoring, accuracy, multipotentiality, and wide applicability in different cell type. For measuring micronucleus, T98G cells were treated with compound 2, 3 and $\mathbf{6}$ under similar conditions and concentrations as were used for growth kinetics and clonogenic assay.

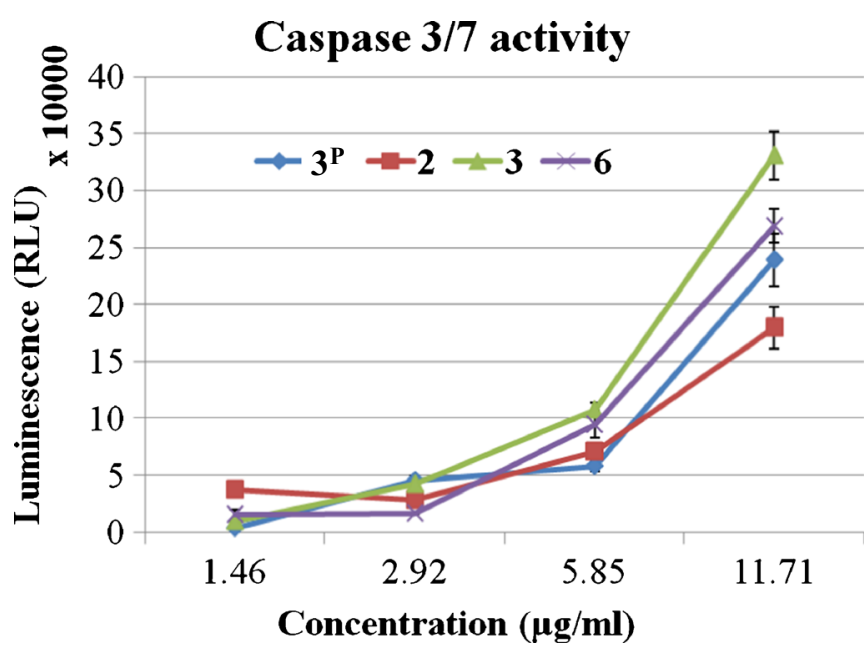

Figure 6. Compounds $3^{P}, \mathbf{2}, \mathbf{3}$ and $\mathbf{6}$ induced activation of caspase $3 / 7$ in T98G cell line. Apoptosis was assessed by measuring active caspase-3/7 using the Promega Caspase3/7 assay kit. Experiments were performed in triplicate and repeated two times.
After treatment by compounds, cell cultures were grown for $24 \mathrm{~h}$ to allow chromosomal damage to lead to the formation of micronuclei in bi- or multinucleated interphase cells. Figure 7 shows micronucleus frequency at $24 \mathrm{~h}$ for T98G brain cancer cells after treatment by $5-25 \mu \mathrm{g} / \mathrm{mL}$ concentration of compound $\mathbf{2}, \mathbf{3}$ and $\mathbf{6}$. The frequency of untreated cells with micronuclei has been in the range of 2-4\%. Notably, treatment with $5 \mu \mathrm{g} / \mathrm{mL}$ of $\mathbf{2 , 3}$ and $\mathbf{6}$ exposure induce a significant level of micronuclei formation in T98G cells, and the range of micronucleus is $7 \%, 9 \%$ and $17 \%$, respectively. The micronuclei frequency increased from $4 \%$ (control) to $12 \%, 19 \%$ and $25 \%$ for $15 \mu \mathrm{g} / \mathrm{mL}$ concentration treated cells with $\mathbf{2}, \mathbf{3}$ and $\mathbf{6}$, respectively, at $24 \mathrm{~h}$ culture. However, $25 \mu \mathrm{g} / \mathrm{mL}$ concentrations of $\mathbf{2}, \mathbf{3}$ and $\mathbf{6}$ further increases micronuclei frequency from $4 \%$ (control) to $15 \%, 26 \%$ and $33 \%$, respectively. The micronuclei in T98G cells is formed by DNA strand breaks generated during the faulty excision repair process due to compound genotoxicity. The remaining unsealed DNA leads to the formation of micronuclei in subsequent mitosis, and cells with micronuclei are found to be associated with loss of reproductive capacity.

3.2g In silico pharmacokinetics: A probable drug molecule, besides having good biological activity, must have good pharmacokinetic accessibility in biological system. To access the pharmacokinetic profile of synthesized molecules, well-validated in-silico tools: Osiris, Chemaxon and Catalyst were used. These tools have been validated with over 7000 drug molecules available in the market. The analysis of theoretical toxicity risks for the synthesized compounds using OSIRIS program shows that compounds $3^{P}, 6^{P}$ and 1-6 are not toxic (score for mutagenicity, tumorigenicity, irritating and reproductive effect is 1) and can be used as the therapeutic molecules (figure 8). On the other side, compounds $\mathbf{1}^{P}, \mathbf{2}^{P}, \mathbf{4}^{P}$ and $\mathbf{5}^{P}$ were found to have some toxicity effect. In particular, compounds $\mathbf{1}^{P}$ and $4^{P}$ showed high mutagenic effects (score 0.6 ) while $\mathbf{2}^{P}$ and $\mathbf{5}^{P}$ showed high reproductive effects (score 0.6). As these compounds were considered for oral delivery, they were submitted to the analysis of Lipinski 'rule of five', drug-likeness and drug score by using catalyst software (table 3 ). The results indicate that all effective molecules $\mathbf{3}^{P}, \mathbf{2}, \mathbf{3}$ and $\mathbf{6}$ fulfil rule and their druglikeness property, such as molecular weight (230-405), Log P (1.49-3.48), nHBA (5-9), nHBD (2-6) and number of rotatable bonds (rotb) (2-4) were similar to the commercial drugs (table 3 ).

Finally, we evaluated all molecules as the potential drugs by calculating their drug-likeness and drug-score. 

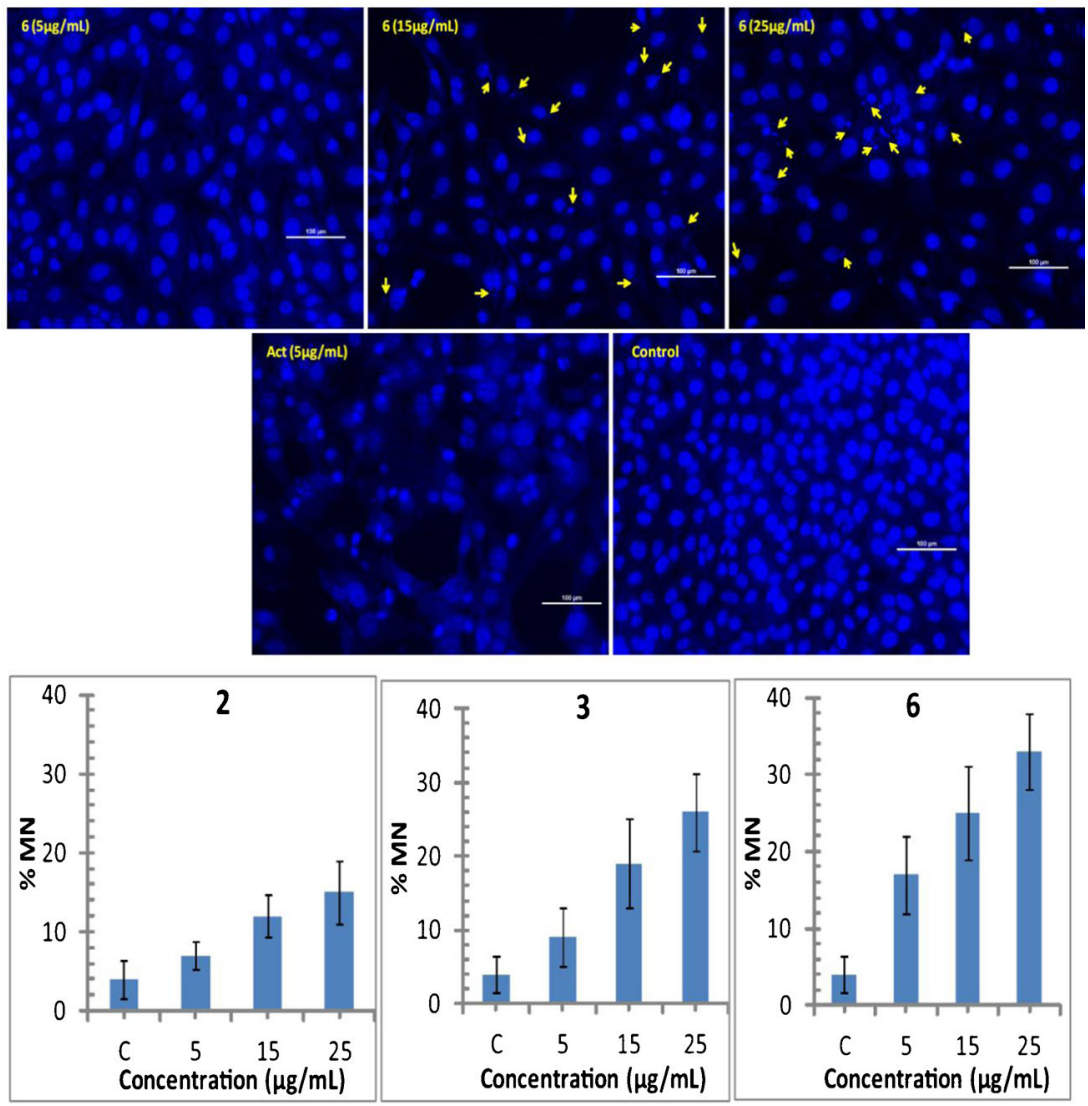

Figure 7. The various treated cells that observed in the micronucleus (MN) assay at concentration 5,15 and $25 \mu \mathrm{g} / \mathrm{ml}$ of compound $\mathbf{2 , 3}$ and $\mathbf{6}$. Control cell groups were treated with medium only and positive control cell population is treated with $5 \mu \mathrm{g} / \mathrm{mL}$ anticancer drug actinomycin D (Act-D). The cells shown with one or many micronucleus were scored for MN. All scale bars are $100 \mu \mathrm{m}$.

Drug-likeness is related to the similarity with the commercial drugs (-2.75-1.74). The drug score for all compounds were in the range of $0.27-0.87$ whereas the drug

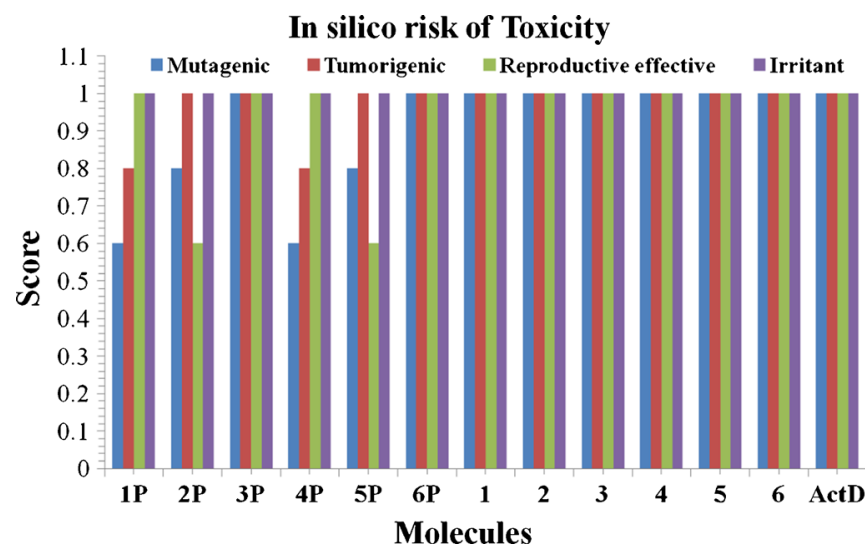

Figure 8. In silico drug safety analysis by Osiris software. High score is considered as indicator for safe drugs (Safe drug: Score 1; Medium Risk: Score 0.9-0.7; High Risk: $<0.7)$. score for the commercial drug, Act-D was 0.42. Importantly, drug score for the commercial drug, Act-D is less than that of our synthesized compounds. Among all molecules, compounds 1-6 showed the best values of drug-score $(0.68-0.87)$ with no toxicity risk, which point towards their further exploration.

It is well-established that subtle structural changes in an organic compound considerably influences its biological activity. A few illustrative examples are discussed here. Shin and co-workers ${ }^{43}$ have reported the anti-amyoidogenic activity of a large number of molecules where a substituted phenol ring is part of the framework. Notably, the position and number of the hydroxyl group onto the arene ring was considered to be an important design criterion for the observed activities. Borges and co-workers ${ }^{44}$ have evaluated the analgesic properties of several hybrid amide-based compounds containing phenol rings where the position of the hydroxyl group onto the arene ring has been varied and was found to significantly affect the pharmacological properties. Kitamura and co-workers ${ }^{45}$ have synthesized a few stilbene derivatives where subtle 
Table 3. Pharmacokinetic parameters (Catalyst, Chemaxon and Osiris softwares).

\begin{tabular}{lrrrrrcc}
\hline Compounds & nHba & nHbd & nrotb & MW & cLog P & Drug-likeness & Drug Score \\
\hline $\mathbf{1}^{P}$ & 7 & 2 & 6 & 377 & 3.07 & 0.05 & 0.27 \\
$\mathbf{2}^{P}$ & 7 & 2 & 6 & 377 & 3.07 & 0.81 & 0.30 \\
$\mathbf{3}^{P}$ & 9 & 2 & 4 & 405 & 3.48 & -2.75 & 0.37 \\
$\mathbf{4}^{P}$ & 4 & 1 & 3 & 228 & 1.99 & 0.26 & 0.35 \\
$\mathbf{5}^{P}$ & 4 & 1 & 3 & 228 & 1.99 & 1.05 & 0.39 \\
$\mathbf{6}^{P}$ & 5 & 1 & 2 & 242 & 2.19 & -2.54 & 0.48 \\
$\mathbf{1}$ & 7 & 4 & 4 & 349 & 2.68 & 1.55 & 0.75 \\
$\mathbf{2}$ & 7 & 4 & 4 & 349 & 2.68 & 1.06 & 0.71 \\
$\mathbf{3}$ & 9 & 6 & 4 & 381 & 2.08 & 0.45 & 0.68 \\
$\mathbf{4}$ & 4 & 2 & 2 & 214 & 1.79 & 1.74 & 0.87 \\
$\mathbf{5}$ & 4 & 2 & 2 & 214 & 1.79 & 1.27 & 0.84 \\
$\mathbf{6}$ & 5 & 3 & 2 & 230 & 1.49 & 0.64 & 0.79 \\
Act-D & 28 & 6 & 8 & 1255 & 0.24 & 7.09 & 0.42 \\
\hline
\end{tabular}

structural changes were noted to control the estrogenic activities; in particular, para-hydroxyl group on the first phenyl ring and peripheral substituent(s) on the second phenyl ring were considered important structural parameters. Zhou and co-workers ${ }^{46}$ have synthesized synthetic analogues of resveratrol and found that the molecules bearing ortho-dihydroxyl or 4-hydroxy-3-methoxyl groups possess significantly higher antioxidant activity than those bearing no such functionalities. These examples adequately illustrate the importance of designed organic molecules containing hybrid functional groups and further show that the position as well as the number of hydroxyl groups on arene ring can influence the biological activities. Interestingly, out of twelve compounds that have been assayed; compounds containing catechol rings ( 3 and 6) displayed high anti-cancer activity. It is therefore suggested that not only type of functional group(s) but also their number and position possibly influence the biological activity of a potential drug molecule.

\section{Conclusions}

Several biologically significant pyridine-amide based compounds were synthesised, characterized and their medicinal applications were investigated. The results of treatment against human T98G brain cancer, H-460 lung cancer and SNU-80 thyroid cancer cells were compared with the non-malignant HEK and MRC-5 cells. All compounds inhibited the growth of T98G, H460, SNU-80, HEK and MRC-5 cells with their $\mathrm{IC}_{50}$ values ranging from 20.55 to $187.35 \mu \mathrm{g} / \mathrm{mL}$ (52.9 to $873.8 \mu \mathrm{M}$ ); however $\mathbf{3}^{P}, \mathbf{2}, \mathbf{3}$ and $\mathbf{6}$ were particularly active $\left(\mathrm{IC}_{50}<100 \mu \mathrm{M}\right)$ against brain cancer cells and showed very less cytotoxicity on non-malignant HEK and MRC-5 cells. In particular, compounds $\mathbf{3}^{P}, \mathbf{2}, \mathbf{3}$ and $\mathbf{6}$ presented the overall best parameters including: (a) high activity against T98G brain cancer cell line; (b) low cytotoxicity on HEK and MRC-5 cells at effective concentrations; (c) low in-silico toxicity risks; (d) good oral bioavailability according to the Lipinski 'rule of five'; and (e) better drug-likeness and drug-score values, nearly similar or better than the commercial drugs. Based on MTT, growth kinetics, clonogenic and ROS measurement assays, it is concluded that treatment has significant inhibitory effect on T98G cell growth and created oxidative stress in the cells. Production of ROS is initiated immediately after treatment with these compounds, followed by micronuclei formation and apoptotic cell death, which is confirmed by $\mathrm{MN}$ and Caspase 3/7 assay. The results suggest that apoptosis occurred in the cells treated with compounds as the level of caspases was increased manifold over the basal level of untreated T98G cells. This could be due to enhanced amount of ROS inside cells, which has been shown to induce apoptosis in several human cancer cells. Decreased viability of T98G cells strongly suggests that the oxidative stress induced by these compounds resulted in the observed cell death or apoptosis. We conclude that the oxidative stress induced by the present compounds leads to sensitization in $\mathrm{T} 98 \mathrm{G}$ malignant cell line due to the accumulation of ROS and compromised redox status. The importance of such work lies in the possibility that the next-generation molecules might be more efficacious as the anticancer agents and our future work is directed towards such a goal.

\section{Supplementary Information}

Figures for NMR spectra, TG analysis and X-ray structure, and tables for FTIR and NMR spectra data can be seen at www.ias.ac.in/chemsci. 


\section{Acknowledgements}

RG acknowledges the Department of Science and Technology (DST) for financial support and CIF-USIC of this university for the instrumental facilities. This work was supported by the National Research Foundation of Korea (NRF) grant funded by the Korea government (MSIP) (NRF-2010-0027963) and Kwangwoon University in 2014. AA and DB thank University Grant Commission (UGC) for their fellowships.

\section{References}

1. Wang J, Hu D Y, He M, Jin L H and Song B A 2012 Chem. Cent. J. 651

2. Liu X H, Tan C X and Weng J Q 2011 Phosphorus Sulfur Silicon. Relat. Elem. 186552

3. Liu X H, Tan C X and Weng J Q 2011 Asian J. Chem. 234064

4. Su N N, Li Y, Yu S J, Zhang X, Liu X H and Zhao W G 2012 Res. Chem. Intermed 2012. doi: 10.1007/s11164-012-0595-9.

5. Xue Y L, Zhang Y G and Liu X H 2012 Asian J. Chem. 245087

6. Liu X H, Pan L, Ma Y, Weng J Q, Tan C X, Li Y H, Shi Y X, Li B J, Li Z M and Zhang Y G 2011 Chem. Biol. Drug Des. 78689

7. Xue Y L, Liu X H and Zhang Y G 2012 Asian J. Chem. 243016

8. Xue Y L, Liu X H and Zhang Y G 2012 Asian J. Chem. 241571

9. Wu J, Yang S, Song B A, Bhadury P S, Hu D Y, Zeng S and Xie H P 2011 J. Heterocycl. Chem. 48901

10. Xiao Y M, Yang X L, Li B, Yuan H Z, Wan S Q, Xu Y J and Qin Z H 2011 Molecules 168945

11. Karolyi B I, Bosze S, Orban E, Sohar P, Drahos L, Gal E and Csampai A 2012 Molecules 172316

12. Chhikara B S, Jean N S, Mandal D, Kumar A and Parang K 2011 Eur. J. Med. Chem. 462037

13. Wu J, Kang S, Song B, Hu D, He M, Jin L and Yang S 2012 Chem. Cent. J. 628

14. Singha N C and Sathyanarayana D N 1997 J. Mol. Struct. 403123 and references therein.

15. Wu R, Zhu C, Du X-J, Xiong L-X, Yu S-J, Liu X-H, Li Z-M and Zhao W-G 2012 Chem. Cent. J. 699

16. (a) Kaushik N K, Mishra A, Ali A, Adhikari J S, Verma A K and Gupta R 2012 J. Biol. Inorg. Chem. 17 1217; (b) Singh A P, Kaushik N K, Verma A K, Hundal G and Gupta R 2009 Eur. J. Med. Chem. 44 1607; (c) Mishra A, Kaushik N K, Verma A K and Gupta R 2008 Eur. J. Med. Chem. 43 2189; (d) Singh A P, Kaushik N K, Verma A K and Gupta R 2011 Ind. J. Chem. 50A 474

17. Solovskij M V, Denisov V M, Panarin E E, Petukhova N A and Purkina A V 1996 Macromol. Chem. Phys. 197 2035

18. Suter C M and Johnson T B $1930 \mathrm{~J}$. Am. Chem. Soc. 52 1585

19. Ali A, Hundal G and Gupta R 2012 Cryst. Growth Des. 121308
20. Kumar G, Aggarwal H and Gupta R 2013 Cryst. Growth Des. 1374

21. Sarma R J and Baruah J B 2007 Cryst. Growth Des. 7 989

22. Brock C P and Duncan L L 1994 Chem. Mater. 61307

23. Kobayashi K, Endo K, Aoyama Y and Masuda H 1993 Tetrahedron Lett. 347929

24. Aoyama Y, Kobayasi K, Endo K and Masuda H 1994 Supramol. Chem. 4229

25. Yoshizawa K, Toyota S, Toda F, Kato M and Csöregh I 2007 Cryst. Eng. Commun. 9786

26. Tominaga M, Katagiri K and Azymaya I 2009 Cryst. Growth Des. 93692

27. Tominaga M, Katagiri K and Azymaya I 2010 Cryst. Eng. Commun. 121164

28. Tominaga M, Masu H and Azumaya I 2011 Cryst. Growth Des. 11542

29. Rho H S, Baek H S, You J W, Kim S J, Kim M-K, Kim D H and Chang I S 2007 Bull. Korean Chem. Soc. 28 837

30. Perrin D D, Armarego W L F and Perrin D R 1980 In Purification of laboratory chemicals (Oxford: Pergamon Press)

31. CrysAlisPro Oxford Diffraction Ltd., version 1.171.33.49b, 2009

32. SMART: Bruker Molecular Analysis Research Tool, version 5.618, Bruker Analytical X ray System, 2000

33. SAINT-NT, Version 6.04, Bruker Analytical X-ray System, 2001.

34. SHELXTL-NT, Version 6.10, Bruker Analytical X-ray System, 2000.

35. Kaushik N K, Kim Y H, Han Y G and Choi E H 2013 Curr. Appl. Phys. 13176

36. Kaushik N K, Kim H S, Chae Y J, Lee Y N, Kwon G C, Choi E H and Kim I T 2012 Molecules 1711456

37. Kaushik N K, Attri P, Kaushik N and Choi E H 2012 Molecules 1713727

38. Kaushik N K, Uhm H S and Choi E H 2012 Appl. Phys. Lett. 10084102

39. http://www.organic-chemistry.org/prog/peo/.

40. Tekto I V 2005 Drug Discovery Today 101497

41. Wenlock M C, Austin R P, Barton P, Davis A M and Leeson P D 2003 J. Med. Chem. 461250

42. A few of the compounds presented in this work have been synthesized using different methods and have been used for assorted purposes. See (a) Reed J E, White A J P, Neidle S and Vilar R 2009 Dalton Trans. 2558; (b) Engers D W, Niswender C M, Weaver C D, Jadhav S, Menon U N, Zamorano R, Conn P J, Lindsley C W and Hopkins C R 2009 J. Med. Chem. 52, 4115; (c) Begouin A and Queiroz M-J R P 2009 Eur. J. Org. Chem. 2820

43. Lee Y S, Kim H Y, Kim Y S, Seo J H, Roh E J, Han H and Shin K J 2012 Bioorg. Med. Chem. 204921

44. Queiroz L M D, Rocha J R, Leitao A, Montanari C A, de Silva A B F, Sousa P J C and Borges R S 2012 Chem. Biol. Drug Des. 80100

45. Sanoh S, Kitamura S, Sugihara K, Fujimoto N and Ohta S 2003 J. Health Sci. 49359

46. Cheng J-C, Fang J-G, Chen W-F, Zhou B, Yang L and Liu Z-L 2006 Bioorg. Chem. 34142 